\title{
Adsorptive removal of antibiotics from water and wastewater: progress and challenges
}

Mohammad Boshir Ahmed, John L Zhou*, Huu Hao Ngo, Wenshan Guo

School of Civil and Environmental Engineering, University of Technology Sydney, Broadway, NSW 2007, Australia

Corresponding author:

Prof John Zhou

School of Civil and Environmental Engineering

University of Technology Sydney

Broadway, NSW 2007

Australia

Tel: +61295142023

Fax: +61295147803

Email: junliang.zhou@uts.edu.au 


\begin{abstract}
Antibiotics as emerging contaminants are of global concern due to the development of antibiotic resistant genes potentially causing superbugs. Current wastewater treatment technology cannot sufficiently remove antibiotics from sewage, hence new and low-cost technology is needed. Adsorptive materials have been extensively used for the conditioning, remediation and removal of inorganic and organic hazardous materials, although their application for removing antibiotics has been reported for $\sim 30$ out of 250 antibiotics so far. The literature on the adsorptive removal of antibiotics using different adsorptive materials is summarized and critically reviewed, by comparing different adsorbents with varying physicochemical characteristics. The efficiency for removing antibiotics from water and wastewater by different adsorbents has been evaluated by examining their adsorption coefficient $\left(\mathrm{K}_{\mathrm{d}}\right)$ values. For sulfamethoxazole the different adsorbents followed the trend: biochar $(\mathrm{BC})>$ multi-walled carbon nanotubes $(\mathrm{MWCNTs})>$ graphite $>$ clay minerals, and for tetracycline the adsorptive materials followed the trend: SWCNT $>$ graphite $>$ MWCNT $=$ $\mathrm{AC}>$ bentonite $=$ humic substance $=$ clay minerals. The underlying controlling parameters for the adsorption technology have been examined. In addition, the cost of preparing adsorbents has been estimated, which followed the order of $\mathrm{BCs}<\mathrm{ACs}<$ ion exchange resins < MWCNTs < SWCNTs. The future research challenges on process integration, production and modification of low-cost adsorbents are elaborated.
\end{abstract}

Keywords: adsorption, antibiotic, biochar, activated carbon, carbon nanotube, regeneration 


\section{Contents}

1. Introduction

2. Adsorptive processes for antibiotic removal

2.1. Activated carbons (ACs)

2.2. Carbon nanotubes (CNTs)

2.3. Clay mineral (bentonite)

2.4. Ion exchange resins

2.5. Biochars (BCs)

3. Antibiotic removal: kinetics, isotherms and mechanism

3.1. Adsorption kinetics

3.2. Adsorption isotherms

3.3. Adsorption mechanism

4. Adsorbent regeneration and adsorbent production cost estimation

4.1. Adsorbent regeneration

4.2. Estimation of adsorbent production cost

5. Integration of adsorption process into existing treatment framework

6. Challenges and future perspectives in removing antibiotics from contaminated water

7. Conclusions

\section{Introduction}

Antibiotics are unique among medicines in that they act selectively on bacteria, among them the pathogens, while leaving human cells and tissues unaffected (Sköld, 2011). Antibiotics can be classified by either their chemical structure or mechanism of action (Table 1). There are over 250 different antibiotic entities registered for use in human and veterinary medicine (Kümmerer and Henninger, 2003). Most of these substances have a microbial origin, but they can also be semi-synthetic or totally synthetic. Antibiotics are the potent medicines that have 
been used for several decades in both human and animals, for therapeutic treatment of infections related diseases, and for protecting their health (Sapkota et al., 2008). Among the various pharmaceuticals, antibiotic usage has been rapidly increased all over the world thus it has received widespread attention (Kasprzyk-Hordern et al., 2009). Of particular concern are antibiotic residues in the environment which can induce antibiotic resistant genes (ARGs) from extended exposure at relatively low concentrations (Dantas et al., 2008). The past and ongoing usage of antibiotics produces significant residues which are directly or indirectly introduced into the aquatic and terrestrial environments (Sarmah et al., 2006), and residues of human and veterinary antibiotics have been detected in many different matrices (Batt et al., 2006; Feitosa-Felizzola and Chiron, 2009; Hirsch et al., 1999; Jacobsen et al., 2004; Lindsey et al., 2001; Mompelat et al., 2009; Ternes, 1998) .

Antibiotics have different half-lives in the environment, some are highly persistent (Daughton and Ternes, 1999), and therefore their contamination levels in the environment have been increasing. Several studies (Ji et al., 2012; Lai et al., 2009; Wollenberger et al., 2000) showed significant impacts that exposure to antibiotics ( $\mu \mathrm{g} / \mathrm{L}-\mathrm{mg} / \mathrm{L})$ may cause on aquatic organisms on their survival, growth and body weight. The release of antibiotics into the natural water bodies mainly comes from the effluents of municipal sewage treatment plants (STPs) and pharmaceutical manufacturing plants. As reviewed by Michael et al. (2013) and Rizzo et al. (2013), urban wastewater treatment plants are likely to be hotspots for the release of antibiotics and ARGs in the natural environment. Thus pharmaceutical chemicals especially antibiotics are gaining the recognition of emerging environment contaminants as being classified as recalcitrant bio-accumulative compounds (Chen and Zhou, 2014), hence antibiotics are regarded as toxic and hazardous chemicals (Hartmann et al., 1998; Lee et al., 2001; Wollenberger et al., 2000) . 
Before discharging wastewater into the environment it is highly important for antibiotic residues to be removed but it usually involves high cost. Case studies of providing cost effective solutions for antibiotic removal are urgently needed (Kim et al., 2005; Košutić et al., 2007; Watkinson et al., 2007). Although processes such as advanced oxidation can convert antibiotic molecules into simple compounds or even mineralize them completely but these processes are very expensive (Mehrjouei et al., 2014) and difficult to maintain for the total removal of compounds including antibiotics at industrial scale. Thus physicochemical technologies are proving to be highly suitable treatment option for organic contaminants. (Homem and Santos, 2011; Wang et al., 2007). Adsorption process is very efficient (Hao et al., 2012; Zhou et al., 2012), simple to design and operate; and it is relatively inexpensive and unaffected by the potential toxicity as for biologically based processes (Ahmaruzzaman, 2008). Adsorption processes are widely used to remove organic contaminants from contaminated stream onto adsorbent surfaces (Han et al., 2008; Homem and Santos, 2011), although their application to antibiotic removal has been reported for around 30 compounds so far. The efficiency of adsorption processes is highly affected by the type of adsorbent, adsorbate properties, and the compositions of waste stream (Aksu and Tunç, 2005). Several adsorptive materials including activated carbon (AC), carbon nanotubes (CNTs) especially multi-walled carbon nanotubes (MWCNTs), natural clay materials such as bentonite, ion exchange materials and biochar (BC) are reviewed for antibiotic removal. However, other adsorbents such as hollow silica nanospheres, $\mathrm{MgO}$ particles, $\mathrm{MgO}$ nanoparticles, $\mathrm{ZnO}-\mathrm{MgO}$ nano-composites and kaolinite are not reviewed (Fakhri and Behrouz, 2015).

Upon realising the significance of antibiotic removal by adsorption technology, the aim of this study is to review and analyze the published studies on the application of adsorptive materials for antibiotic removal. Specifically this review will cover (i) the behaviour of adsorptive materials for removing antibiotics from wastewater in both static and dynamic regimes; (ii) the mechanism, kinetics and equilibria of adsorption process; and (iii) the 
progress and future challenges of the adsorptive materials including cost consideration and regeneration studies.

\section{Adsorptive processes for antibiotic removal}

The term adsorption is the accumulation of matter from a gas or liquid phase to the surface of an adsorbent, which could involve physical and/or chemical adsorption. Although adsorption is a well-known process, in the past decades the study of this technology for antibiotic removal has not been extensively explored. The most widely reported adsorbents for antibiotic removal include ACs, CNTs, bentonite, ion exchange resins and BCs. Overviews of published journal articles for antibiotic removal by adsorptive materials are presented in Tables 2-6. In most of the adsorption studies, the concentrations of antibiotics used are at $\mathrm{mg} / \mathrm{L}$ level, which are significantly higher than environmentally relevant concentrations (ng/L - $\mu \mathrm{g} / \mathrm{L})$. To ensure a consistent comparison between different adsorbents, the discussion often referred to the linear range of the adsorption isotherms by calculating the adsorption coefficient $\left(\mathrm{K}_{\mathrm{d}}\right)$. The adsorption efficiency is directly related to the adsorbent's properties such as specific surface area (SSA), porosity (macro or micro porosity), pore diameter and functional groups (Estevinho et al., 2007).

\subsection{ACs}

ACs have been widely used to remove organic contaminants from water and wastewater in industrial scale applications and more recently in removing pharmaceuticals from sewage effluent (Grover et al., 2011). High degree of micro porosity, well developed surface area, and high adsorption capacity are the key features of ACs (both granular and powdered) that make them suitable as adsorbent for the removal of organic contaminants (Huang et al., 2011; Jain et al., 2004; Roosta et al., 2014a; Roosta et al., 2014b). However, the main drawbacks of ACs are their high production cost and high regeneration costs (Aksu and Tunç, 2005), and the 
adsorption of antibiotics on their surface is significantly influenced by their characteristics such as surface physical morphology and functionality (Foo and Hameed, 2012). Recent studies on using ACs for antibiotic removal have shown that ACs or modified ACs have potential applications for significant remediation of various antibiotics from wastewater, with an efficiency varying from $74 \%$ to $100 \%$ (Torres-Pérez et al., 2012; Pouretedal and Sadegh, 2014). During batch adsorption of nitroimidazoles on $\mathrm{AC}$, it was found that the $\mathrm{pH}$ of the medium and the electrolyte concentration did not influence the adsorption process (RiveraUtrilla et al., 2009). A 90\% removal efficiency of nitroimidazoles and trimethoprim was obtained by using AC (PAC and GAC) (Kim et al., 2010; Méndez-Díaz et al., 2010) as shown in Table 2. In another study over 90\% adsorption removal efficiency (Tables 2) for trimethoprim, sulphonamides (sulfachloropyridazine, sulfadimethoxine, sulfamerazine, sulfamethazine and sulfathiazole), carbadox and tetracycline was achieved using PAC as adsorbent (Adams et al., 2002; Pouretedal and Sadegh, 2014, Torres-Perez et al., 2012).

As shown in Table 2, in a study of the adsorptive removal of amoxicillin using AC and bentonite, high removal efficiencies were achieved by AC (95\%) than by bentonite $(88 \%)$ (Putra et al., 2009). Another study reported that $99 \%$ amoxicillin was removed by $\mathrm{NH}_{4} \mathrm{Cl}-$ induced $\mathrm{AC}$ at $\mathrm{pH} 6$ and $50^{\circ} \mathrm{C}$ (Moussavi et al., 2013). Using $\mathrm{AC}$ produced from vine wood it was found that the removal of different classes of antibiotics such as amoxicillin, cephalexin, cephalosporin, penicillin $\mathrm{G}$ and tetracycline varied between $74 \%$ and $88 \%$ as summarized in Table 2 (Pouretedal and Sadegh, 2014). In addition, even 100\% removal of sulfamethoxazole (Stackelberg et al., 2007) and other pharmaceuticals (Grover et al., 2011) was observed. Furthermore, it was reported that $\mathrm{NaOH}-\mathrm{AC}$ produced from macadamia nut shells presented a high surface area $\left(1524 \mathrm{~m}^{2} / \mathrm{g}\right)$ with a maximum adsorptive capacity (Table 2$)$ for the removal of tetracycline from aqueous solution (Martins et al., 2015). Although AC, in particular GAC has higher rate of success for the removal of antibiotics from aqueous medium, its high cost 
and difficulty of regeneration are two major disadvantages constraining its wider application at commercial scale (Crisafully et al., 2008).

\subsection{CNTs}

Engineered CNTs (single and multiwall) have recently shown great promise for many remediation applications including pharmaceutical chemicals such as antibiotics since the discovery of CNTs in 1991 (Kim et al., 2014b; Singh et al., 2014). CNTs contain cylindrical layered graphite sheets with a characteristically large surface area which have high van der Waals index (Schwarzenbach et al., 2005). The benzenoid rings of graphite sheets have high polarizability due to the presence of $\mathrm{sp}^{2}$-hybridized carbon atoms. These properties of CNTs make them super hydrophobic materials that can interact with aromatic pollutants by $\pi-\pi$ coupling stacking (Long and Yang, 2001; Lara et al., 2014). The removal of antibiotics such as sulphonamides, lincomycine, and amoxicillin by CNTs has been studied in fixed bed columns or batch mode under a broad range of conditions, and great removal success $(80 \%$ to $>$ 90\%) has been reported (Ji et al., 2009b; Kim et al., 2014a; Mohammadi et al., 2015).

In recent remediation of antibiotics from aqueous environments, about $90 \%$ removal of lincomycin and sulfamethoxazole (sulphonamides) was found from aqueous solutions on SWCNT and MWCNT (Kim et al., 2014a). Kim et al. (2014a) also reported that SWCNT had a greater efficiency than other adsorbents in the order: SWCNT > PAC > MWCNT as detailed in Table 3. In another study it was reported that about $96 \%$ adsorptive removal of sulfamethoxazole and sulfapyridine occurred in a fixed bed column of CNTs, where contact periods were only $2 \mathrm{~h}$ (Tian et al., 2013). In batch mode, an adsorptive removal efficiency of sulfamethoxazole and sulfapyridine on CNTs and graphite was found to be $80 \%$ as shown in Table 3 (Ji et al., 2009b). An 86.5\% adsorptive removal of amoxicillin from aqueous media

was also found using MWCNT (Table 2) (Mohammadi et al., 2015). However, CNTs may not 
be widely applicable due to their high material cost (Esawi and Farag, 2007). In future, the low cost production of CNTs should be a high priority in adsorption research.

\subsection{Clay mineral (bentonite)}

Clay mineral e.g. bentonite is an adsorbent of aluminium phyllosilicate, which has high surface area and pore volume. Bentonite can act as an adsorbent for the remediation of antibiotics from water and wastewater. Up to now, antibiotic removal by bentonite has not been widely explored, only a few literature reports have been found. In batch mode, the adsorption of ciprofloxacin from aqueous solution on bentonite was found to be very high with $99 \%$ removal efficiency, with a contact time of 30 min at $\mathrm{pH} 4.5$ (Genç et al., 2013). In another study (Table 4) for the removal of ciprofloxacin on using bentonite, AC, zeolite and pumice, it was observed that bentonite achieved the highest removal capacity (Genç and Dogan, 2015). They also calculated the Gibbs free energy $\left(\Delta \mathrm{G}^{\circ}\right)$ values of adsorption by bentonite, zeolite, AC and pumice which appeared in the order: bentonite $>\mathrm{AC}>$ zeolite $>$ pumice.

On the other hand, during amoxicillin removal from real wastewater on bentonite and $\mathrm{AC}$, bentonite efficiency (88\%) was found to be less than using AC (95\%); and neither adsorbent can completely remove amoxicillin due to the sorption competition from other substances which were also present in the wastewater (Putra et al., 2009). Thus the performance of bentonite is sometimes higher or almost comparable with $\mathrm{AC}$ in the removal of antibiotics such as amoxicillin and ciprofloxacin from wastewater (Genç et al., 2013; Putra et al., 2009)..

\subsection{Ion exchange resins}

Ion exchange is a process in which cations or anions in a liquid medium are exchanged with cations or anions on a solid sorbent, and electro-neutrality is maintained in both phases. Overall it was found that ion exchange resin materials can remove antibiotics from water and 
wastewater with efficiency up to $90 \%$. As shown in Table 5, the adsorption removal efficiency of tetracyclines and sulphonamides on ion exchanger were $>80 \%$ and $~ 90 \%$ respectively (Choi et al., 2007). In another study on the removal of sulfamethazine using ion exchange materials about $100 \%$ sulfamethazine removal was achieved in all cycles (Fernández et al., 2014b). However for the removal of quinoxaline derivatives (carbadox) and sulphonamides (sulfachloropyridazine, sulfadimethoxine, sulfamerazine and sulfathiazole) using ion exchange resin, it was reported that ion exchange method may not be appropriate (Adams et al., 2002). In batch mode, the removal of a mixture of sulfamethoxazole and sulfamethazine using a strong anionic resin was successfully carried out with a higher capacity of adsorption for sulfamethoxazole; furthermore, $100 \%$ of both compounds were recovered during the elution stage (Fernández et al., 2014a). Ion exchangers can therefore remove some antibiotics from wastewater significantly. However the problems associated with this type of materials are backwashing and regeneration, with additional problems such as the appearance of fouling and potential irreversible accumulation (Üstün et al., 2007).

\subsection{BCs}

The interest for alternative adsorbents rather than $\mathrm{AC}$ is growing with the purpose of finding new low-cost yet effective adsorbents, from by-products or waste materials derived from industrial or agricultural processes. $\mathrm{BC}$ is a potential alternative to $\mathrm{AC}$ that could be used for antibiotic removal. The raw materials for $\mathrm{BC}$ production can be obtained from agricultural biomass and solid waste which are abundant with little cost (Xu et al., 2013). BC can be prepared by various methods and has many interesting properties such as low cost, highly porous structure and high removal capacities for organic and inorganic pollutants from aqueous solution (Ahmed et al., 2014b). For example, BC is usually produced under a temperature range of $300-1000^{\circ} \mathrm{C}$ in the presence or absence of minimal oxygen $(\leq 2 \%)$ through the process of slow or fast pyrolysis. These kinds of treatment convert the biomass 
materials into products with a high surface area owing to porous structure. In addition, enriched surface functional groups make BC suitable to be used as a prominent adsorbent for antibiotic removal from aqueous stream (Rajapaksha et al., 2014). As an adsorbent, BC has the porous structure almost similar to AC and thus can act as an efficient sorbent for the removal of diverse pollutants from water and wastewater (Chen et al., 2007; Faria et al., 2004; Nakagawa et al., 2004). BC can be produced at a lower cost than AC, where higher temperature and additional activating agent may be required. In most cases, BC does not require additional activation process like $\mathrm{AC}$ for the removal of antibiotics although some researchers (Azargohar and Dalai, 2008; Uchimiya et al., 2012) have performed BC activation using different activating materials. In particular, it is speculated that activation of $\mathrm{BC}$ by steam and/or $\mathrm{N}_{2}$ purging may enhance its sorption tendency (Rajapaksha et al., 2014; Rajapaksha et al., 2015). Thus, the overall production of BC is significantly cheaper than AC as reported in the literature (Cao et al., 2009; Zheng et al., 2010; Karakoyun et al., 2011; Ahmad et al., 2012a; Lu et al., 2012).

Antibiotic sorption to BC may vary greatly according to antibiotic properties as well as BC properties (Yao et al., 2012; Zhang et al., 2013). Moreover, BCs exhibited similar or even better adsorption capacity than commercially available ACs as being reported in several studies (Karakoyun et al., 2011; Xue et al., 2012; Zhang et al., 2012; Yang et al., 2014). BC can act as a dominant adsorbent for the removal of antibiotics as it has shown very high degrees of removal (up to 100\%) depending on antibiotic classes. In studying the adsorptive removal of sulfonamides (sulfamethoxazole and sulfapyridine) on BC (Table 6), it was reported that pinewood $\mathrm{BC}$ which was prepared under different thermochemical conditions exhibited strong adsorption capacity (Yao et al., 2012; Xie et al., 2014). In addition, the high removal efficiencies of up to $100 \%$ for antibiotics florfenicol and ceftiofur were achieved on pinewood BC (Table 6) which demonstrated the potential of BC as an effective adsorbent for removing antibiotics from sewage and other contaminated effluents (Mitchell et al., 2015). 
Teixido et al. (2011) reported a high $\mathrm{K}_{\mathrm{d}}$ value $\left(10^{6} \mathrm{~L} / \mathrm{kg}\right)$ for the removal of sulfamethazine on BC while Liu et al. (2012) observed the maximum adsorption capacity $(58.8 \mathrm{mg} / \mathrm{g})$ for tetracycline on biomass-derived BC.

Based on the available data for different adsorbents such as BC, MWCNT, graphite and clay minerals (Zheng et al., 2013; Ji et al., 2009b; Thiele-Burhn et al., 2004), the relationship between $\mathrm{K}_{\mathrm{d}}$ for sulfamethoxazole and adsorbents is shown in Figure 1, suggesting that these adsorptive materials followed the general trend of $\mathrm{BC} 600>\mathrm{BC} 500>\mathrm{MWCNT}>$ graphite $=$ clay minerals. However for the removal of tetracycline (Figure 2), adsorptive materials followed a different trend: SWCNT $>$ graphite $>$ MWCNT $=\mathrm{AC}>$ bentonite $=$ humic substance $=$ clay minerals $(\mathrm{Ji}$ et al., 2009a $)$.

In summary, adsorption technology can be applied for removing different antibiotics from water and wastewater containing a whole suite of other inorganic and organic components, often with a very high efficiency. To ensure the wide application of adsorption technology at commercial scale, the cost reduction in the preparation of effective adsorbents will remain to be a constraining factor, and to that end $\mathrm{BC}$ preparation has the greatest potential for exploitation as a research topic (Liu et al., 2012; Teixido et al., 2011; Yao et al., 2012).

\section{Antibiotics removal: kinetics, isotherms and mechanism}

\subsection{Adsorption kinetics}

The kinetics of adsorption not only determine the rate of antibiotic removal from water and wastewater, but also the size and capital cost of actual adsorption system required for commercial applications. Adsorption kinetics typically involve four steps: bulk transport, film transport, intra-particle transport and adsorption on the adsorbent. Often the rate controlling step is film transport which is governed by molecular diffusion in the boundary layer. Kinetic modelling is performed to investigate the rate of the controlling steps during the removal of antibiotics from solution by adsorbents. There are different differential equations being used 
for kinetic modelling in both batch and continuous system; these equations are solved by using integral method (Han et al., 2009). Many different kinetic models have been used including zero order, first order or pseudo first order, second order or pseudo second order and third order to describe the kinetics of adsorption. Kinetic parameters such as the rate constants, equilibrium adsorption capacities and related correlation coefficients for pseudo first-order and second-order kinetic models were discussed and summarized in Tables 7a and 7b. Some of the parameters are described below, including the effects of initial concentrations of adsorbate and adsorbent and contact time on the kinetics of adsorption.

\section{Effect of initial concentrations of adsorbate and adsorbent}

The initial relative concentrations of adsorbate and adsorbent will determine when the adsorption becomes saturated, with the consequence of adsorbate leaving without treatment causing a breakthrough. Thus different antibiotics will potentially have different equilibration time to reach their maximum efficiency. For example, the breakpoint time was found to decrease from 37.4 to $25.6 \mathrm{~min}$ for sulfamethoxazole, and from 51.8 to $25.5 \mathrm{~min}$ for sulfapyridine as the initial concentration of the antibiotics was quadrupled (Tian et al., 2013). In general, an increase in adsorbate concentration can lead to a lower removal efficiency. On the other hand, an increase in adsorbent dosage will result in a better removal efficiency although the operating cost will increase.

\section{Effect of contact time between adsorbent and adsorbate}

The contact time between adsorbate and adsorbent is a key kinetic parameter. In general, it is preferred that the contact time between adsorbate and adsorbent will be kept at minimum while maximum removal can be achieved. However, due to adsorption kinetic controls longer than minimum time, i.e. optimum time is required to ensure sufficient removal of antibiotics is obtained by reaching a dynamic equilibrium (Genç et al., 2013). For example, the rate of penicillin removal was found to reach equilibrium after 48-72 h regardless of the nature of carbon adsorbents, where most of the uptake occurred within the first $24 \mathrm{~h}$ (Ania et al., 2011). 
A complete adsorptive removal of amoxicillin occurred on $50 \mathrm{mg} / \mathrm{L}$ of $\mathrm{NH}_{4}-\mathrm{Cl}$ induced AC (NAC) within first 20 min. The high $\mathrm{r}^{2}$ value of NAC and standard AC for the adsorption of amoxicillin indicated that the kinetic results were best described by the pseudo second order kinetic model (Moussavi et al., 2013). Good fitness to pseudo second order model was also found for the adsorption of amoxicillin onto AC and bentonite at $\mathrm{pH} 2.31$ (Table 7b) (Putra et al., 2009). The kinetics of tetracycline adsorption onto ACs (Table 7a) followed a very fast decrease in concentration within the first $12 \mathrm{~h}$, followed by a slow decrease depending on the adsorbent materials (Torres-Pérez et al., 2012). Based on the correlation coefficients $\left(\mathrm{r}^{2}>0.98\right)$ of adsorption kinetic models of different antibiotics (amoxicillin, cephalexin, penicillin G and tetracycline) on AC (Table 7b), it was found that pseudo second order provided the best fit; and the adsorption mechanism was suggested to be chemisorption (Pouretedal and Sadegh, 2014). The equilibrium contact time was found to be $8 \mathrm{~d}$ to reach for the adsorptive removal of imidazoles when using $0.1 \mathrm{mg} / \mathrm{L}$ of AC (Rivera-Utrilla et al., 2009). On the other hand, the equilibrium contact time of sulfamethoxazole adsorption on waste based carbon was found to be significantly faster at 15 to 30 min (Table 7a) (Calisto et al., 2015). It was also mentioned that the experimental data was best described by pseudo second order with a $\mathrm{r}^{2}$ value of 0.991 , and maximum adsorption capacity $\left(\mathrm{q}_{\max }\right)$ was found to be 118 mg/g. On the other hand, tetracycline adsorption on $\mathrm{NaOH}$-induced $\mathrm{AC}$ reached an equilibrium at about 120 min with a $\mathrm{r}^{2}$ value of 0.960 (Table $7 \mathrm{a}$ ), which indicated that the adsorption kinetics followed pseudo second order (Martins et al., 2015).

Adsorption of sulfamethoxazole on BC (Table 7a) reached equilibrium within $72 \mathrm{~h}$ and neutral sulfamethoxazole $\left(\mathrm{SMX}^{0}\right)$ was dominant at $\mathrm{pH}$ 1.0-6.0, and above 7.0 BC surface became negatively charged while the sorption of negatively charged sulfamethoxazole ( $\mathrm{SMX}^{-}$ ) species increased with increasing $\mathrm{pH}$ (Zheng et al., 2013). It is shown in Table $7 \mathrm{~b}$ that the adsorption of lincomycine on SWCNTS and MWCNT reached an equilibrium within $100 \mathrm{~h}$ and adsorption kinetics involved two phases: a rapid step which was followed by a slow step. 
It was also found that SWCNT had the higher potential to adsorb lincomycine and sulfamethoxazole than MWCNT (Kim et al., 2014a).

In using bentonite as adsorbent, it was reported that the pseudo second order model (Table $7 b)$ fitted the kinetic data very well $\left(\mathrm{r}^{2}>0.99\right)$ at low $\mathrm{pH}$ value, which was due to the chemisorption of amoxicillin being dominant (Ho, 2006; Putra et al., 2009). In a batch kinetic study for the adsorption of sulfamethazine on bentonite (Table 7a), it was found that $120 \mathrm{~min}$ was needed to reach an equilibrium (Fernández et al., 2014b). For adsorptive removal of ciprofloxacin (Table 7b) on bentonite, AC, zeolite and pumice, it was observed that the pseudo second order kinetic model was the best model for fitting the data with $r^{2}$ value of 0.999 (Genç \& Dogan, 2015). The equilibrium time (Table 7a) for batch adsorptive removal on strong anion exchanger was found to be $120 \mathrm{~min}$ and $100 \mathrm{~min}$, respectively for sulfamethoxazole and sulfamethazine, and for sulfamethazine (Fernández et al., 2014a; Fernández et al., 2014b), which is relatively fast for the adsorption process.

\subsection{Adsorption isotherms}

Equilibrium isotherms are widely used to represent the relationship between the adsorbed concentration in the adsorbent phase and the dissolved concentration at equilibrium. Such isotherms are a characteristic feature for a specific system at particular environmental conditions. There are several adsorption isotherm models such as the Langmuir, Freundlich, Brunauer-Emmett-Teller (BET), Temkin, Frumkin, Harkins-Jura, Smith, and DubininRadushkevich (D-R) isotherms. The Langmuir model assumes monolayer adsorption on adsorbents which have homogeneous energy distribution, the Freundlich isotherm is an empirical model suitable for heterogeneous surface adsorption, and the D-R isotherm model is valid for the adsorption of low concentration of contaminants onto both homogeneous and heterogeneous surfaces. The equilibrium adsorption isotherms for some antibiotic compounds

are shown in Tables $7 \mathrm{a}$ and $7 \mathrm{~b}$. For $\mathrm{BC}$ adsorbent, the adsorption of antibiotics 
sulfamethoxazole and sulfapyridine was well fitted with the Freundlich sorption model $\left(\mathrm{r}^{2}>\right.$ 0.96). For three $\mathrm{BC}$ samples namely $\mathrm{BC} 400, \mathrm{BC} 500$ and $\mathrm{BC} 500 \mathrm{H}$, it was found that the adsorption isotherms were highly nonlinear and the degree of nonlinearity followed the order: BC500H > BC500 > BC400 (Xie et al., 2014). The isotherms of sulfamethoxazole sorption on nondeashed $\mathrm{BC}$ was found to be fitted by both Freundlich and Dubinin models with the adjusted coefficient $r^{2}>0.952$ (Table 7a) (Xie et al., 2014). The isotherms of sulfamethoxazole on BC was almost linear $(n=0.919)$, implying that the antibiotic partitioning into the non-carbonized organic matter was dominant (Chen et al., 2008a). With increasing pyrolytic temperature from 300 to $600^{\circ} \mathrm{C}$, the $\mathrm{n}$ values were decreased to 0.198 , which revealed more heterogeneous glassy, hard or condensed sorption dominating on BC surfaces with high sorption distribution energy (Xing et al., 1996; Zhang et al., 2011).

For CNT adsorbent, the adsorption of lincomycine was not well fitted by the Langmuir isotherm $\left(\mathrm{r}^{2}<0.70\right)$, indicating that the adsorption was not of pure monolayer type. In comparison, the Freundlich model (Table 7a) was better suited to the adsorption data with $\mathrm{r}^{2}>$ 0.93 , and values of $\mathrm{n}$ were substantially smaller than 1 suggesting more heterogeneous adsorption sites on the adsorbents. The highest value of Freundlich affinity constant $\left(\mathrm{K}_{\mathrm{F}}\right)$ obtained from the isotherms was from SWCNTs, and the general trend was SWCNT > PAC > MWCNT (Kim et al., 2014a). It was proposed that the attraction of acceptor-acceptor, and acceptor-donor pairs between the antibiotics (sulfamethoxazole and sulfamethazine) and the CNTs were responsible for the observed strong adsorption of antibiotics onto CNTs at lower pH values (Tian et al., 2013). In another study of the adsorption of amoxicillin on CNT, three models namely the Langmuir, Freundlich and D-R were found to provide a good fit to the adsorption data $\left(\mathrm{r}^{2}>0.91\right)$, and the Langmuir isotherm (Table $\left.7 \mathrm{~b}\right)$ provided the best fit $\left(\mathrm{q}_{\max }\right.$ value $23.458 \mathrm{mg} / \mathrm{g}, \mathrm{b}_{\mathrm{L}}$ value $\left.2.5 \times 10^{-5} \mathrm{~L} / \mathrm{mol}, \mathrm{r}^{2}>0.99\right)$, indicating saturated monolayer sorption (Mohammadi et al., 2015). The Freundlich adsorption isotherm provided the best fit for the removal of sulfonamide with adsorption nonlinearity (as indicated by the smaller $n$ 
values) (Ji et al., 2009b). The adsorption isotherms of sulfamethoxazole, tetracycline, and tyrosine were also well fitted by the Freundlich isotherm model (Table $7 a)\left(r^{2}>0.98\right)$ with $n$ value significantly smaller than 1 , which reflected that the adsorption was consistently highly nonlinear (Ji et al., 2010).

For AC adsorbent, the $\mathrm{r}^{2}$ values of the Langmuir isotherm were greater than those of other isotherms which indicated that amoxicillin molecular adsorption occurred as monolayer (Table 7b). It was also found that the maximum monolayer adsorption capacities were 262 and $437 \mathrm{mg} / \mathrm{g}$, respectively for standard $\mathrm{AC}$ and $\mathrm{NH}_{4}-\mathrm{Cl}$ induced $\mathrm{AC}$ (Moussavi et al., 2013). Another study on standard AC for the adsorption of tetracycline revealed that the Freundlich model proved to be the best fit $\left(\mathrm{r}^{2}>0.985\right)$, and the maximum adsorption capacity $\left(\mathrm{q}_{\max }=817\right.$ mg/g) was observed for a commercially available GAC2 (Torres-Pérez et al., 2012). It was also found (Table $7 b$ ) that the Langmuir isotherm $\left(r^{2}>0.980\right.$ and higher $\left.b_{L}\right)$ provided the best fit for the removal of amoxicillin, cephalexin, penicillin G and tetracycline on AC (Pouretedal and Sadegh, 2014). The correlation coefficient value $\left(\mathrm{r}^{2}>0.99\right)$ on AC (Table 7b) indicated that the Langmuir isotherm was the best fit and the constant $\left(b_{L}\right)$ increased in the order: dimetroimidazole $>$ metronidazole $>$ ronidazole $>$ tinidazole, which might be related to the decreased solubility of these nitroimidazoles in water with increasing absorption energy (Rivera-Utrilla et al., 2009). Sulfamethoxazole adsorption on waste based AC was found to be best matched with the Freundlich isotherm $\left(r^{2}=0.987\right)$ with $K_{F}$ value of $0.308 \pm 0.008 L^{n}$ $\mathrm{mmol}^{1-\mathrm{n}} / \mathrm{kg}$ (Calisto et al., 2015). For the adsorption of tetracycline on $\mathrm{NH}_{4}-\mathrm{Cl}$ induced $\mathrm{AC}$ (Table 7a), isotherm models of the Langmuir, Freundlich and Temkin also provided a good fit to the experimental data (Martins et al., 2015). The $n$ value (14.63) from the Freundlich isotherm indicated that the physisorption was favourable.

For bentonite adsorbent, the Langmuir model was found to provide the best fit for the adsorption of amoxicillin (Putra et al., 2009) with $\mathrm{r}^{2}$ of 0.9886 and $\mathrm{q}_{\max }$ of $53.9 \mathrm{mg} / \mathrm{g}$. Similarly the Langmuir model was found to be more suitable than the Freundlich model for 
the adsorption of ciprofloxacin on bentonite with $r^{2}$ value of 0.939 and $q_{\max }$ value of 147.1 mg/g (Genç et al., 2013).

For ionic exchange resins (Table 7a), the adsorption isotherm of sulfamethazine on strong anionic resin in a fixed bed showed that the Langmuir model correlated with the experimental data well, with $\mathrm{r}^{2}$ value of 0.981 and $\mathrm{q}_{\max }$ value of $110 \mathrm{mg} / \mathrm{g}$ (Fernández et al., 2014b). In another study, it was found that the Langmuir model was the best fit for the adsorption of sulfamethoxazole and sulfamethoxazole on strong anion exchanger resin (Fernández et al., 2014a).

It can be summarized that antibiotic adsorption on different adsorbents followed different pattern, with $\mathrm{BC}$ and $\mathrm{CNT}$ following multi-layer coverage whilst $\mathrm{AC}$, bentonite and ion exchange resin followed monolayer coverage.

Some of the factors that affect adsorption isotherms are described below:

\section{Affinity of adsorbate to adsorbent}

Affinity of adsorbate is a prime factor that governs the mechanism of adsorptive materials. In general, if the affinity of adsorbate molecule to adsorbent surface is high then there is a high tendency for adsorption to take place. The adsorption of ionic compounds was greatly governed by the electrostatic interaction between adsorbent surface and adsorbate (Lertpaitoonpan et al., 2009; Tolls, 2001). It was found that the strength of adsorbateadsorbent interactions may modify due to a screening effect in the presence of electrolyte solution (Radovic et al., 2001). The affinity of adsorbate is also dependent on the properties of the adsorbate molecules.

\section{Physicochemical characteristics of adsorbate and adsorbent}

The surface of adsorbent raw materials such as bentonite appears to be closely packed flacks in contrast to the ragged appearance of the thermal activated structure (Toor and Jin, 2012). After thermal activation, adsorptive materials gave the appearance of a more porous structure due to interlayer spaces collations. Moreover, some chemical activation of adsorptive 
materials generated a more porous structure as well as more oxygenated functional groups on their surfaces than thermal activation only (Malik et al., 2006; Toor and Jin, 2012). The changes in molecular structure and chemical composition of the adsorbents depend upon the activation methods and conditions to be used for specific adsorbate removal. Excessive heating may lead to irreversible collapse of structure and interlayer spaces of the adsorbents.

The edges of the platelets porous surface are first to be attacked by the adsorbate molecules as it is more virgin. Thus different interactions between adsorbate and adsorbent surface occur between surface of the adsorbent and the active site of the adsorbate. In general, the increase in surface area of adsorbents provides a better chance for more interactions with adsorbate molecules. The pore size of the adsorbent may be either macro or micro in nature depending on the raw material and activation methods.

\section{Effect of temperature}

The effect of temperature on the adsorption of antibiotic molecules by adsorbent can be calculated by thermodynamic equations:

$$
\begin{aligned}
\Delta \mathrm{G}^{\circ} & =\Delta \mathrm{H}^{\circ}-\mathrm{T} \Delta \mathrm{S}^{\circ} \\
\Delta \mathrm{G}^{\circ} & =-\mathrm{RT} \ln \mathrm{K}_{\mathrm{c}}
\end{aligned}
$$

where $\Delta \mathrm{G}^{\circ}$ is the Gibbs free energy, $\Delta \mathrm{H}^{\circ}$ is the total enthalpy of the solution, $\Delta \mathrm{S}^{\circ}$ is the entropy of the reaction in solution, $R$ is the universal gas constant $(8.314 \mathrm{~J} / \mathrm{mol} \mathrm{K}), \mathrm{K}_{\mathrm{c}}$ is the equilibrium constant representing the ability of the adsorbent to retain the adsorbate and extent of movement of the adsorbate within the solution, and $\mathrm{T}$ is the absolute temperature (K). In general, the adsorption reactions are exothermic and spontaneous with negative $\Delta \mathrm{H}^{\circ}$ and $\Delta \mathrm{G}^{\circ}$ values and higher degree of randomness for positive $\Delta \mathrm{S}^{\circ}$ value (Lian et al., 2009; Pouretedal and Sadegh, 2014). For the endothermic adsorption reactions, positive value of $\Delta \mathrm{H}^{\circ}$ indicates that the adsorption of organic molecules onto the surface of the solid involve a chemical reaction which may be due to the protonation, hydrogen bond formation or van der Waals forces (Pouretedal and Sadegh, 2014). For example, in studying the adsorption of 40 
$\mathrm{mg} / \mathrm{L}$ of ciprofloxacin using bentonite and $\mathrm{AC}$, negative $\Delta \mathrm{G}^{\circ}$ values $(-4340$ and $-843 \mathrm{~J} / \mathrm{mol})$, positive $\Delta \mathrm{H}^{\circ}$ values $(8662$ and $7739 \mathrm{~J} / \mathrm{mol})$, and positive $\Delta \mathrm{S}^{\circ}$ values $(44.1$ and $29.1 \mathrm{~J} / \mathrm{mol} \mathrm{K})$ were observed for bentonite and $\mathrm{AC}$, respectively at $22^{\circ} \mathrm{C}$. The results indicated that some structural changes were occurring on the adsorbent surfaces, and the randomness at the solidliquid interface was increased during the adsorption process (Genç and Dogan, 2015).

\section{Effect of solution pH}

The solution $\mathrm{pH}$ is a critical parameter for an effective interaction between adsorbate and adsorbent (Acemioğlu, 2004). The influence of $\mathrm{pH}$ on adsorption is mainly dependent on the type of carbonaceous materials and the target contaminants. It not only affects the adsorbent surface charge but also affects the degree of ionization and speciation of the adsorbate (Kołodyńska et al., 2012; Li et al., 2013; Regmi et al., 2012). As carbonaceous materials carry various surface functional groups mainly oxygen containing groups e.g. $-\mathrm{COOH}$ and $-\mathrm{OH}$, thus the behaviour of these functional groups changes with solution $\mathrm{pH}$. When the $\mathrm{pH}$ of the solution is increased or decreased then the percentage of removal may change as a result, thus the optimum $\mathrm{pH}$ for the effective removal of specific antibiotics should be determined. For example, in the $\mathrm{pH}$ range of $1.0-6.0, \mathrm{SMX}^{0}$ was dominant and the $\mathrm{BC}$ surface was negative; but at $\mathrm{pH}>7.0, \mathrm{SMX}^{-}$was dominant $(>71.5 \%)$ and the $\mathrm{BC}$ surfaces were strongly negative (Zheng et al., 2013). Therefore, the molecules being adsorbed and the extent of their adsorption are highly dependent on solution for those ionisable compounds. It was observed that $\mathrm{NaOH}$-induced $\mathrm{AC}$ showed approximately $100 \%$ removal of tetracycline at $\mathrm{pH} 3.0,80 \%$ at $\mathrm{pH} 4.0$, and $70 \%$ at $\mathrm{pH}$ greater than 5.0 , hence the optimum $\mathrm{pH}$ was 3.0 for tetracycline removal (Martins et al., 2015). However, for some antibiotics solution $\mathrm{pH}$ did not have a major effect for their removal as shown for nitroimidazoles when solution $\mathrm{pH}$ was between 4 and 11 (Rivera-Utrilla et al., 2009). 
The adsorption of adsorbate molecule may be dominated by the specific driving force, e.g. $\pi$ $\pi$ electron-donar-acceptor (EDA) interaction with $\pi$-electron rich surface and the aromatic ring of adsorbents.

\subsection{Adsorption mechanism}

In general, electrostatic interaction (cation and anion attractions), hydrophobic effect (hydrophobic interaction), hydrogen bonds, partition into un-carbonized fractions, pore filling, and other processes (surface precipitation, $\pi-\pi$ interactions) are the main mechanism for the adsorption of antibiotics onto the carbon-based adsorbents such as AC and BC (Tan et al., 2015). Adsorption phenomenon of contaminants involves four steps: (i) solute transportation in the bulk, (ii) film diffusion of adsorbate, (iii) pores diffusion of adsorbate diffusion, (iv) adsorption - interaction between adsorbate and porous structure. These interactions are strong and more specific than physical adsorption and they are limited to the monolayer coverage (Cooney, 1999).

The potentially different and diverse adsorption mechanism by which antibiotics bind to carbon materials (BC, $\mathrm{CNT}$ and $\mathrm{AC}$ ) are shown in Figure 3. The internal properties of adsorptive materials play a major role in the adsorption of organic compounds as those materials have heterogeneous surface area due to co-existing carbonized and non-carbonized fractions, which possess different adsorption mechanism. It was suggested that sulphonamides adsorption on different $\mathrm{BCs}$ well correlated with the amount of graphitization which indicated that $\pi-\pi$ EDA interaction between the adsorbate molecules and the graphite surfaces of the BC was the predominant adsorption mechanism (Xie et al., 2014). Sorption of sulfamethoxazole on $\mathrm{BC}$ at low $\mathrm{pH}(1.0-6.0)$ was dominated by the specific driving force, $\pi-\pi$ EDA interaction of the protonated aniline ring with the $\pi$-electron rich graphite surface referring to as $\pi^{+}-\pi$ EDA, rather than ordinary electrostatic cation exchange. Above $\mathrm{pH} 7.0$ anionic 
sulfamethoxazole species sorption was increased and became regulated via charge-assisted hydrogen bonds (Teixidó et al., 2011; Zheng et al., 2013).

By studying the kinetic data, it was assumed that the mechanism of antibiotic adsorption on $\mathrm{AC}$ was a chemical reaction i.e. chemisorption (Pouretedal and Sadegh, 2014). It was mentioned that the electronic density of nitroimidazoles with their aromatic rings increased their adsorption on $\mathrm{AC}$ and enhanced the chance of $\pi-\pi$ adsorbate-adsorbent dispersion interactions. Hence the adsorption process was mainly determined by the adsorbent-adsorbate dispersion interactions (Rivera-Utrilla et al., 2009). However, it was reported that $\mathrm{NH}_{4} \mathrm{Cl}$ induced AC may show similar mechanism i.e. electrostatic interaction, hydrogen bonding formation, electron donor-acceptor, and $\pi-\pi$ dispersion interaction (Vargas et al., 2011; Martins et al., 2015).

Adsorption heterogeneity and hysteresis are two features of antibiotic-CNT interactions. However, different mechanism may act simultaneously, mainly hydrophobic interactions, $\pi-\pi$ bonds, electrostatic interactions and hydrogen bonds, hence the prediction of antibiotic adsorption on CNTs is not straightforward. The dominant adsorption mechanism is different for different types of antibiotics (such as polar and nonpolar), thus different models may be needed to predict antibiotic-CNT interaction. Adsorption mechanism will be better understood by investigating the effects of properties of both CNTs and antibiotics along with the environmental conditions such as solution $\mathrm{pH}$, temperature and matrix (Pan and Xing, 2008). It was reported that the adsorption of very hydrophilic antibiotics (lincomycine and sulfamethoxazole) on SWCNTs might include electrostatic interactions and hydrogen bonds, in addition to hydrophobic interactions (Kim et al., 2014a). On the other hand, it was highly expected that sulfamethoxazole and sulfamethoxazole interacted with the polarized aromatic rings on the surface of CNTs via the mechanism of $\pi$ - $\pi$ electron coupling (Ji et al., 2009b). It was proposed that $\pi-\pi$ EDA interaction between $\pi$ electron acceptor compounds and the $\pi$ electron rich regions of the grapheme surface of CNTs, and graphite occurred during 
adsorption (Chen et al., 2008b; Ji et al., 2009a). A similar mechanism was found on $\mathrm{KOH}-$ activated CNT for the adsorption of sulfamethoxazole, tetracycline and tyrosine (Ji et al., 2010).

In general, bentonite has different mechanisms for adsorptive removal of contaminants (Putra et al., 2009). The first mechanism was cation exchange where low valence cations in bentonite structure $\left(\mathrm{Al}^{3+}, \mathrm{Mg}^{2+}, \mathrm{Fe}^{3+}, \mathrm{Na}^{+}, \mathrm{Ka}^{+}\right.$and $\mathrm{Ca}^{2+}$ ) were exchanged by protonated functional groups within amoxicillin (amoxicillin has positive charge due to the protonation of amoxicillin carboxyl and amine groups by the presence of free $\mathrm{H}^{+}$ions in the solution). For carboxyl and amine groups the protonation took place as follows but phenol groups were not protonated on amoxicillin (Andreozzi et al., 2005).

$$
\begin{array}{ll}
\equiv \mathrm{COO}^{-}+\mathrm{H}^{+} \rightarrow \equiv \mathrm{COOH} & \text { (There will be free protons when } \mathrm{pH} \text { is <2.68) } \\
\equiv \mathrm{COOH} \rightarrow \equiv \mathrm{COO}^{-}+\mathrm{H}^{+} & \text {(above } \mathrm{pH} \text { value of } 2.68) \\
\equiv \mathrm{NH}_{2}+\mathrm{H}^{+} \rightarrow \equiv \mathrm{NH}_{3}{ }^{+} & \text {(below } \mathrm{pH} \text { value of 7.49) }
\end{array}
$$

The second mechanism was via interactions between the protonated groups (aluminol and silanol) in bentonite and carboxyl groups in antibiotics. The dominant mechanism of ciprofloxacin adsorption on bentonite was cation exchange. FQ molecules appear to be better suited for cation exchange than for cation bridging or surface complexion. At $\mathrm{pH} 4.5$, cation exchange between the protonated heterocyclic ( $\mathrm{N}$ atom) of positively charged ciprofloxacin $\left(\mathrm{CIP}^{+}\right)$and negatively charged montmorillionite surface occurred at $\mathrm{pH} 7.0$, the carboxylic anion was the dominant species and thus carboxylic group of negatively charged ciprofloxacin $\left(\mathrm{CIP}^{-}\right)$interacted with montmorillionite surface (Genç and Dogan, 2015; Pei et al., 2009; Yan et al., 2013b).

\section{Adsorbent regeneration and adsorbent production cost estimation}

\subsection{Adsorbent regeneration}


Recovery of saturated adsorbent is one of the most important steps in the adsorptive removal of contaminant, as the feasibility of an industrial adsorption process largely depends on the cost of regeneration of spent adsorbents which can be reused subsequently. After being saturated with contaminants, the regeneration of adsorptive precursors is dependent on the type of adsorbents. For example, for carbonaceous materials (AC, BC and CNT) thermal decomposition processes are most widely used. There are three thermal methods for the regeneration of carbonaceous materials namely (i) pyrolysis, (ii) pyrolysis-gasification and (iii) gasification. Pyrolysis and gasification techniques for $\mathrm{AC}$ regeneration in a thermo balance at different ranges were carried out using air or $\mathrm{CO}_{2}\left(200 \mathrm{~cm}^{3} / \mathrm{min}\right)$ under $\mathrm{N}_{2}$ flow, and it was observed that air gasification achieved the best result as air had no cost with minimum time contact of $3 \mathrm{~h}$ (Sabio et al., 2004). Other regeneration methods involve chemical and solvent (e.g. $\mathrm{NaOH}, \mathrm{HCl}, \mathrm{NaCl}$ ), microbiological, electrochemical, ultrasonic, and wet air oxidation approaches. If the solvent regeneration method is to be used then solvent consumption should be much less than that by water (Tamon et al., 1990). For example, the regeneration of $\mathrm{AC}$ was done using 5\%w/w of $\mathrm{NaOH}$ (Pouretedal and Sadegh, 2014).

To regenerate CNT columns loaded with sulfamethoxazole and sulfapyridine, a solution containing $30 \mathrm{~g} / \mathrm{L} \mathrm{NaCl}$ and $1.5 \mathrm{~g} / \mathrm{L} \mathrm{NaOH}$ of $\mathrm{pH} 12$ was used, with an excellent recovery of 97\% for sulfamethoxazole and $91 \%$ for sulfapyridine, respectively (Tian et al., 2013). Tian et al. (2013) also observed that each regeneration cycle reduced the capacity of the adsorption bed by $8-26 \%$ for both antibiotics, but permitted the column to be reused multiple times with an acceptable antibiotic sorption capacity. It was also reported that total amoxicillin from MWCNT can be regenerated using $0.1 \mathrm{~mol} / \mathrm{L}$ of $\mathrm{NaOH}$ and $\mathrm{HCl}$, followed by distilled water (Mohammadi et al., 2015). Bentonite can be regenerated using $\mathrm{NaOH}$ as solvent (Peng et al., 2005), and can also be regenerated by thermal treatment (Lin and Cheng, 2002). Once desorbed, the antibiotic-loaded solvents should be disposed carefully e.g. by incineration to 
eliminate pollution as well as utilizing the energy content of solvents, as otherwise antibiotics will be transferred from water to another phase. For highly concentrated chlorine containing solvents, flue gas from incineration should be purified for removing chlorine before emission.

\subsection{Estimation of adsorbent production cost}

The adsorbent precursors are mostly produced form agricultural (e.g. biomass), industrial (e.g. timber) and municipal (e.g. sewage) solid waste. Each of individual preparation process of adsorptive precursors has different reagents and equipment cost The total cost of adsorptive materials can be calculated by equation 3:

Total cost $=$ Production cost + Regeneration cost + Process loss cost

The production cost involves raw material and adsorbent preparation, and in most cases the raw material cost is relatively low or even negligible, depending on local precursor availability. Using $\mathrm{BC}$ as an example, its cost depends on the local supply of raw materials, processing requirement, reactor availability, pyrolysis parameters, value added coproducts production, and material recycling in their life cycle (Mohan et al., 2014).

For CNTs, their operational cost in wastewater treatment could be lower than for other commercial carbon sorbents such as ACs (Tian et al., 2013). CNTs can perform as better adsorbents under many circumstances than ACs (Pan and Xing, 2008). But the problem associated with CNTs is that in most cases their adsorption is not reversible and production cost therefore becomes too high. For example, by studying 44 commercially available CNTs, it was found that the average price was in the range of $\$ 1,500-\$ 10,000 / \mathrm{kg}$ and $\$ 45,000$ $\$ 140,000 \$ / \mathrm{kg}$, respectively for MWCNTs and SWCNTs (Cho et al., 2008; Apul and Karanfil, 2015). In comparison, ACs can be available at a substantially lower price range of $\$ 2-5 / \mathrm{kg}$ (Babel and Kurniawan, 2003; Lin and Juang, 2009).

Furthermore, BCs as adsorbents are inexpensive or even have negligible cost. Their production technique is also very inexpensive and does not consume costly reagents, in 
comparison to $\mathrm{AC}$ production and activation which require high temperature and expensive reagents. Based on literature data, the cost of different $\mathrm{BC}$ production has been calculated and summarized as being in a range of $\$ 0.2-0.5 / \mathrm{kg}$ based on the frequently reported data, and focusing on the woody waste $\mathrm{BC}$ rather than hardwood as environmentally and socially it is more sustainable to utilize woody wastes than hardwood (Dickinson et al., 2014). The authors therefore concluded that $\mathrm{BC}$ as an effective adsorbent can potentially be produced with low carbon foot print, hence highly beneficial for water treatment whilst minimizing other environmental damage such as greenhouse effect. Other adsorbent such as ion exchange resin may cost up to $\$ 150 / \mathrm{kg}$ (Wang et al., 2011). A comparative price chart showed that the adsorbent cost followed the order of SWCNTs $>$ MWCNTs $>$ ion exchange resins $>$ ACs $>$ BCs (Figure 4).

\section{Integration of adsorption process into existing treatment framework}

Currently antibiotics are removed from water or wastewater either by batch process or continuous process using adsorptive materials such as ACs, CNTs, bentonite, ion exchange resins and BCs. As one treatment technology cannot remove all contaminants from wastewater completely, it is necessary to combine more than one treatment into an integrated system. In future, considering the different treatment processes and advantages of the adsorption technology, it is necessary to study the integration of adsorption process into existing wastewater treatment system. Already, some integrated or hybrid systems (Purnell et al., 2015; Quist-Jensen et al., 2015; Rondon et al., 2015) have been developed and used by combining with other technologies such as membrane reactor (MR), membrane bioreactor (MBR), high retention membrane bioreactor (HR-MBR) (Luo et al., 2014), anaerobic membrane bioreactor (AMBR), enhanced membrane bioreactor (eMBR), filtration, osmosis, reverse osmosis, ozonolysis, chlorination, photocatalysis, aeration, anaerobic and aerobic bioreactors. These technologies may be merged or supplemented with the adsorption 
technology. Some of the new integration treatment systems can be (i) MBR $\rightarrow$ adsorptive process , (ii) MBR $\rightarrow$ activated sludge $\rightarrow$ adsorptive process, (iii) MBR $\rightarrow$ biological $\mathrm{AC} \rightarrow$ adsorptive process, (iv) MBR $\rightarrow$ biological AC $\rightarrow$ adsorptive process $\rightarrow$ photocatalysis, (v) $\mathrm{AMBR} \rightarrow$ biological AC $\rightarrow$ adsorptive process $\rightarrow$ photocatalysis, (vi) AMBR $\rightarrow$ adsorptive process $\rightarrow$ UV filtration $\rightarrow$ photocatalysis, and other potential combinations. The combined treatment will improve the removal of recalcitrant or poorly degraded antibiotics and other trace organic contaminants, as a result of the highly efficient adsorption technology.

\section{Challenges and future perspectives in removing antibiotics from contaminated water}

Water is becoming ever more polluted in various ways leading to concern for human and animal health. The extensive use of antibiotics for therapeutic treatment of infections related diseases in human and animals has caused antibiotic contamination of different water bodies globally. The rapid growth and development in and around urban areas and industrial complexes together with population growth have raised both the importance and requirement of appropriate wastewater treatment facilities with increasingly complex implementation. Thus, the important challenges for the $21^{\text {st }}$ century in the field of antibiotics removal from wastewater in general and adsorptive technology specifically include addressing (i) the role of science in the development of stringent regulations and water quality standards preventing antibiotics being discharged from different sources; (ii) issues with establishing infrastructure for the centralized collection of antibiotic contaminated wastewater; (iii) advanced wastewater treatment technology targeted at effective antibiotic removal; (iv) waste-derived low cost adsorptive materials with a high capacity for antibiotic removal; (v) final disposal of antibiotics-loaded adsorbents; and (vi) life cycle analysis of novel adsorptive materials in order to minimize their carbon footprint.

Some of the future research perspectives include: 
- In-depth cost-benefit analysis of adsorptive materials (e.g. BCs) including their production and regeneration using different methods.

- Development of fully-integrated adsorption systems combining different technologies by considering all the important factors such as treatment requirement.

- Establishing large-scale supply chains for the continuous production of adsorptive materials with high yield and low cost.

- Development of effective and low-cost regeneration techniques for BCs and other similar adsorbents.

- Maximizing the adsorptive capacity of adsorbents by modifying their surface structure with novel functional groups in order to achieve high selectivity and specificity.

- Experimenting with multiple or mixture adsorbents with potentially better performance.

- More studies are needed to examine the effect of competition from co-solutes in solution on antibiotic removal by adsorption.

\section{Conclusions}

The removal of antibiotic residues from water and wastewater by adsorption technology has been critically reviewed based on extensive scientific reports. It can be summarized that adsorption is an effective method for antibiotic removal from contaminated waters with an efficacy of $90-100 \%$ at $\mathrm{mg} / \mathrm{L}$ concentration range. The most widely used adsorbents with effective removal are ACs, CNTs and BC. For the removal of sulfamethazole, it was found that adsorptive materials followed the order of BC600 > BC500 > MWCNT > graphite $=$ clay minerals, while for the removal of tetracycline, adsorptive materials followed the trend: SWCNT $>$ graphite $>$ MWCNT $=$ AC $>$ bentonite $=$ humic substance $=$ clay minerals. The high material cost and potential high regeneration costs are the major drawbacks for both ACs and CNTs. In comparison, BCs can be prepared at a significantly lower cost with equal or better adsorptive capacity for antibiotic removal, hence should be explored further. It was 
found that the cost of adsorbents followed the order of SWCNTs $>$ MWCNTs $>$ ion exchange resins > ACs > BCs. Adsorption equilibrium was well modelled by either the Langmuir isotherm or the Freundlich isotherm, while adsorption kinetics often followed pseudo second order. The mechanism of antibiotic adsorption potentially involved $\pi-\pi$ EDA interactions, electrostatic interactions, hydrophobic interaction, hydrogen bonds, and pore filling. Further research should focus on improved understanding of adsorption mechanism, in order to prepare functionalized adsorbents with better specificity and selectivity for antibiotics. In addition, research efforts should be directed to pilot scale or even commercial scale adsorption experiments so that the operating cost of adsorption technology can be fully evaluated. With thorough knowledge of molecular adsorption mechanism, better methods of regenerating spent adsorbents, and full cost-benefit analysis of commercial adsorption columns, the application of low-cost and highly effective adsorbents such as BCs in removing antibiotic residues from waste streams will become widely adopted in safeguarding our precious water resources. 


\section{References}

Acemioğlu, B. 2004. Adsorption of congo red from aqueous solution onto calcium-rich fly ash. J. Colloid Interf. Sci. 274(2), 371-379.

Adams, C., Wang, Y., Loftin, K., Meyer, M. 2002. Removal of antibiotics from surface and distilled water in conventional water treatment processes. J. Environ. Eng. 128(3), 253-260.

Ahmad, M., Lee, S.S., Dou, X., Mohan, D., Sung, J.-K., Yang, J.E., Ok, Y.S. 2012a. Effects of pyrolysis temperature on soybean stover-and peanut shell-derived biochar properties and TCE adsorption in water. Bioresour. Technol. 118, 536-544.

Ahmad, M., Rajapaksha, A.U., Lim, J.E., Zhang, M., Bolan, N., Mohan, D., Vithanage, M., Lee, S.S., Ok, Y.S. 2014b. Biochar as a sorbent for contaminant management in soil and water: a review. Chemosphere, 99, 19-33.

Ahmaruzzaman, M. 2008. Adsorption of phenolic compounds on low-cost adsorbents: a review. Advances in Colloid and Interface Science, 143(1), 48-67.Aksu, Z., Tunç, Ö. 2005. Application of biosorption for penicillin $G$ removal: comparison with activated carbon. Process Biochem. 40(2), 831-847.

Andreozzi, R., Canterino, M., Marotta, R., Paxeus, N. 2005. Antibiotic removal from wastewaters: the ozonation of amoxicillin. J. Hazard. Mater. 122(3), 243-250.

Ania, C.O., Pelayo, J.G., Bandosz, T.J. 2011. Reactive adsorption of penicillin on activated carbons. Adsorption 17(3), 421-429.

Apul, O.G., Karanfil, T. 2015. Adsorption of synthetic organic contaminants by carbon nanotubes: a critical review. Water Res. 68, 34-55.

Azargohar, R., Dalai, A. 2008. Steam and KOH activation of biochar: Experimental and modeling studies. Microporous and Mesoporous Mater. 110(2), 413-421.

Babel, S., Kurniawan, T.A. 2003. Low-cost adsorbents for heavy metals uptake from contaminated water: a review. J. Hazard. Mater. 97(1), 219-243. 
Batt, A.L., Snow, D.D., Aga, D.S. 2006. Occurrence of sulfonamide antimicrobials in private water wells in Washington County, Idaho, USA. Chemosphere 64(11), 1963-1971.

Calisto, V., Ferreira, C.I., Oliveira, J.A., Otero, M., Esteves, V.I. 2015. Adsorptive removal of pharmaceuticals from water by commercial and waste-based carbons. J. Environ. Manage. 152, 83-90.

Cao, X., Ma, L., Gao, B., Harris, W. 2009. Dairy-manure derived biochar effectively sorbs lead and atrazine. Environ. Sci. Technol. 43(9), 3285-3291.

Chen, B., Zhou, D., Zhu, L. 2008a. Transitional adsorption and partition of nonpolar and polar aromatic contaminants by biochars of pine needles with different pyrolytic temperatures. Environ. Sci. Technol. 42(14), 5137-5143.

Chen, J., Chen, W., Zhu, D. 2008b. Adsorption of nonionic aromatic compounds to singlewalled carbon nanotubes: effects of aqueous solution chemistry. Environ. Sci. Technol. 42(19), 7225-7230.

Chen, K., Zhou, J. 2014. Occurrence and behavior of antibiotics in water and sediments from the Huangpu River, Shanghai, China. Chemosphere 95, 604-612.

Chen, W., Parette, R., Zou, J., Cannon, F.S., Dempsey, B.A. 2007. Arsenic removal by ironmodified activated carbon. Water Res. 41(9), 1851-1858.

Cho, H.-H., Smith, B.A., Wnuk, J.D., Fairbrother, D.H., Ball, W.P. 2008. Influence of surface oxides on the adsorption of naphthalene onto multiwalled carbon nanotubes. Environ. Sci. Technol. 42(8), 2899-2905.

Choi, K.-J., Son, H.-J., Kim, S.-H. 2007. Ionic treatment for removal of sulfonamide and tetracycline classes of antibiotic. Sci. Total Environ. 387(1), 247-256.

Cooney, D.O. 1999. Adsorption Design for Wastewater Treatment. CRC Press, Boca Raton, 190 pp.

Crisafully, R., Milhome, M.A.L., Cavalcante, R.M., Silveira, E.R., De Keukeleire, D., Nascimento, R.F. 2008. Removal of some polycyclic aromatic hydrocarbons from 
petrochemical wastewater using low-cost adsorbents of natural origin. Bioresour. Technol. 99(10), 4515-4519.

Dantas, G., Sommer, M.O., Oluwasegun, R.D., Church, G.M. 2008. Bacteria subsisting on antibiotics. Science 320(5872), 100-103.

Daughton, C.G., Ternes, T.A. 1999. Pharmaceuticals and personal care products in the environment agents of subtle change. Environ. Health Perspect. 107, 907-938.

Dickinson, D., Balduccio, L., Buysse, J., Ronsse, F., van Huylenbroeck, G., Prins, W. 2014. Cost-benefit analysis of using biochar to improve cereals agriculture. GCB Bioenergy DOI: 10.1111/gcbb.12180.

Esawi, A.M.K., Farag, M.M. 2007. Carbon nanotube reinforced composites: potential and current challenges. Mater. Design 28(9), 2394-2401.

Estevinho, B.N., Martins, I., Ratola, N., Alves, A., Santos, L. 2007. Removal of 2, 4dichlorophenol and pentachlorophenol from waters by sorption using coal fly ash from a Portuguese thermal power plant. J. Hazard. Mater. 143(1), 535-540.

Fakhri, A., Behrouz, S. 2015. Comparison studies of adsorption properties of MgO nanoparticles and $\mathrm{ZnO}-\mathrm{MgO}$ nanocomposites for linezolid antibiotic removal from aqueous solution using response surface methodology. Process Saf. Environ. Prot. 94, 37-43.

Faria, P., Orfao, J., Pereira, M. 2004. Adsorption of anionic and cationic dyes on activated carbons with different surface chemistries. Water Res. 38(8), 2043-2052.

Feitosa-Felizzola, J., Chiron, S. 2009. Occurrence and distribution of selected antibiotics in a small Mediterranean stream (Arc River, Southern France). J. Hydrol. 364(1), 50-57.

Fernández, A.M.L., Rendueles, M., Díaz, M. 2014a. Competitive retention of sulfamethoxazole (SMX) and sulfamethazine (SMZ) from synthetic solutions in a strong anionic ion exchange eesin. Solvent Extr. Ion Exc. 32(7), 763-781. 
Fernández, A.M.L., Rendueles, M., Díaz, M. 2014b. Sulfamethazine retention from water solutions by ion exchange with a strong anionic resin in fixed bed. Separ. Sci. Technol. 49(9), 1366-1378.

Foo, K., Hameed, B. 2012. Coconut husk derived activated carbon via microwave induced activation: effects of activation agents, preparation parameters and adsorption performance. Chem. Eng. J. 184, 57-65.

Genç, N., Dogan, E.C. 2015. Adsorption kinetics of the antibiotic ciprofloxacin on bentonite, activated carbon, zeolite, and pumice. Desalination Water Treat. 53(3), 785-793.

Genç, N., Dogan, E.C., Yurtsever, M. 2013. Bentonite for ciprofloxacin removal from aqueous solution. Water Sci. Technol. 68(4), 848-855.

Grover, D. P., Zhou, J. L., Frickers, P. E., Readman, J. W. 2011. Improved removal of estrogenic and pharmaceutical compounds in sewage efluent by full scale granular activated carbon: impact on receiving river water. J. Hazard. Mater. 185 (2), 1005-1011.

Han, R., Ding, D., Xu, Y., Zou, W., Wang, Y., Li, Y., Zou, L. 2008. Use of rice husk for the adsorption of congo red from aqueous solution in column mode. Bioresour. Technol. 99(8), 2938-2946.

Han, R., Zhang, J., Han, P., Wang, Y., Zhao, Z., Tang, M. 2009. Study of equilibrium, kinetic and thermodynamic parameters about methylene blue adsorption onto natural zeolite. Chem. Eng. J. 145(3), 496-504.

Hao, R., Xiao, X., Zuo, X., Nan, J., Zhang, W. 2012. Efficient adsorption and visible-light photocatalytic degradation of tetracycline hydrochloride using mesoporous BiOI microspheres. J. Hazard. Mater. 209, 137-145.

Hartmann, A., Alder, A.C., Koller, T., Widmer, R.M. 1998. Identification of fluoroquinolone antibiotics as the main source of umuC genotoxicity in native hospital wastewater. Environ. Toxicol. Chem.17(3), 377-382. 
Hirsch, R., Ternes, T., Haberer, K., Kratz, K.-L. 1999. Occurrence of antibiotics in the aquatic environment. Sci. Total Environ. 225(1), 109-118.

Ho, Y.-S. 2006. Review of second-order models for adsorption systems. J. Hazard. Mater. 136(3), 681-689.

Homem, V., Santos, L. 2011. Degradation and removal methods of antibiotics from aqueous matrices-a review. J. Environ. Manage. 92(10), 2304-2347.

Huang, L., Sun, Y., Wang, W., Yue, Q., Yang, T. 2011. Comparative study on characterization of activated carbons prepared by microwave and conventional heating methods and application in removal of oxytetracycline (OTC). Chem. Eng. J. 171(3), 1446-1453.

Jacobsen, A.M., Halling-Sørensen, B., Ingerslev, F., Hansen, S.H. 2004. Simultaneous extraction of tetracycline, macrolide and sulfonamide antibiotics from agricultural soils using pressurised liquid extraction, followed by solid-phase extraction and liquid chromatographytandem mass spectrometry. J. Chromatogr. A 1038(1), 157-170.

Jain, A.K., Gupta, V.K., Jain, S., Suhas. 2004. Removal of chlorophenols using industrial wastes. Environ. Sci. Technol. 38(4), 1195-1200.

Ji, K., Kim, S., Han, S., Seo, J., Lee, S., Park, Y., Choi, K., Kho, Y.L., Kim, P.G., Park, J. 2012. Risk assessment of chlortetracycline, oxytetracycline, sulfamethazine, sulfathiazole, and erythromycin in aquatic environment: are the current environmental concentrations safe? Ecotoxicol. 21, 2031-2050.

Ji, L., Chen, W., Duan, L., Zhu, D. 2009a. Mechanisms for strong adsorption of tetracycline to carbon nanotubes: A comparative study using activated carbon and graphite as adsorbents. Environ. Sci. Technol. 43(7), 2322-2327.

Ji, L., Chen, W., Zheng, S., Xu, Z., Zhu, D. 2009b. Adsorption of sulfonamide antibiotics to multiwalled carbon nanotubes. Langmuir 25(19), 11608-11613. 
Ji, L., Shao, Y., Xu, Z., Zheng, S., Zhu, D. 2010. Adsorption of monoaromatic compounds and pharmaceutical antibiotics on carbon nanotubes activated by $\mathrm{KOH}$ etching. Environ. Sci. Technol. 44(16), 6429-6436.

Karakoyun, N., Kubilay, S., Aktas, N., Turhan, O., Kasimoglu, M., Yilmaz, S., Sahiner, N. 2011. Hydrogel-biochar composites for effective organic contaminant removal from aqueous media. Desalination 280(1), 319-325.

Kasprzyk-Hordern, B., Dinsdale, R.M., Guwy, A.J. 2009. The removal of pharmaceuticals, personal care products, endocrine disruptors and illicit drugs during wastewater treatment and its impact on the quality of receiving waters. Water Res. 43, 363-380.

Kim, H., Hwang, Y.S., Sharma, V.K. 2014a. Adsorption of antibiotics and iopromide onto single-walled and multi-walled carbon nanotubes. Chem. Eng. J. 255, 23-27.

Kim, H.J., Choi, K., Baek, Y., Kim, D.-G., Shim, J., Yoon, J., Lee, J.-C. 2014b. Highperformance reverse osmosis CNT/polyamide nanocomposite membrane by controlled interfacial interactions. ACS Appl. Mater. Interf. 6(4), 2819-2829.

Kim, S., Eichhorn, P., Jensen, J.N., Weber, A.S., Aga, D.S. 2005. Removal of antibiotics in wastewater: effect of hydraulic and solid retention times on the fate of tetracycline in the activated sludge process. Environ. Sci. Technol. 39(15), 5816-5823.

Kim, S., Shon, H., Ngo, H.H. 2010. Adsorption characteristics of antibiotics trimethoprim on powdered and granular activated carbon. J. Indust. Eng. Chem. 16(3), 344-349.

Kołodyńska, D., Wnętrzak, R., Leahy, J., Hayes, M., Kwapiński, W., Hubicki, Z. 2012. Kinetic and adsorptive characterization of biochar in metal ions removal. Chem. Eng. J. 197, 295305.

Košutić, K., Dolar, D., Ašperger, D., Kunst, B. 2007. Removal of antibiotics from a model wastewater by RO/NF membranes. Separ. Purif. Technol. 53(3), 244-249.

Kümmerer, K., Henninger, A. 2003. Promoting resistance by the emission of antibiotics from hospitals and households into effluent. Clin. Microbiol. Infec. 9(12), 1203-1214. 
Lai, H.-T., Hou, J.-H., Su, C.-I., Chen, C.-L. 2009. Effects of chloramphenicol, florfenicol, and thiamphenicol on growth of algae Chlorella pyrenoidosa, Isochrysis galbana, and Tetraselmis chui. Ecotoxicol. Environ. Safety 72(2), 329-334.

Lara, I.V., Zanella, I., Fagan, S.B. 2014. Functionalization of carbon nanotube by carboxyl group under radial deformation. Chem. Phys. 428, 117-120.

Lee, M., Lee, H., Ryu, P. 2001. Public health risks: Chemical and antibiotic residues-review. Asian-Australasian J. Anim. Sci. 14(3), 402-413.

Lertpaitoonpan, W., Ong, S.K., Moorman, T.B. 2009. Effect of organic carbon and pH on soil sorption of sulfamethazine. Chemosphere 76(4), 558-564.

Li, M., Liu, Q., Guo, L., Zhang, Y., Lou, Z., Wang, Y., Qian, G. 2013. Cu (II) removal from aqueous solution by Spartina alterniflora derived biochar. Bioresour. Technol. 141, 83-88.

Lian, L., Guo, L., Guo, C. 2009. Adsorption of congo red from aqueous solutions onto Cabentonite. J. Hazard. Mater. 161(1), 126-131.

Lin, S.-H., Juang, R.-S. 2009. Adsorption of phenol and its derivatives from water using synthetic resins and low-cost natural adsorbents: a review. J. Environ. Manage. 90(3), 13361349.

Lin, S., Cheng, M. 2002. Adsorption of phenol and m-chlorophenol on organobentonites and repeated thermal regeneration. Waste Manage. 22(6), 595-603.

Lindsey, M.E., Meyer, M., Thurman, E. 2001. Analysis of trace levels of sulfonamide and tetracycline antimicrobials in groundwater and surface water using solid-phase extraction and liquid chromatography/mass spectrometry. Anal. Chem. 73(19), 4640-4646.

Liu, P., Liu, W.-J., Jiang, H., Chen, J.-J., Li, W.-W., Yu, H.-Q. 2012. Modification of bio-char derived from fast pyrolysis of biomass and its application in removal of tetracycline from aqueous solution. Bioresour. Technol. 121, 235-240.

Long, R.Q., Yang, R.T. 2001. Carbon nanotubes as superior sorbent for dioxin removal. J. Amer. Chem. Soc. 123(9), 2058-2059. 
Lu, H., Zhang, W., Yang, Y., Huang, X., Wang, S., Qiu, R. 2012. Relative distribution of Pb 2+ sorption mechanisms by sludge-derived biochar. Water Rese. 46(3), 854-862.

Luo, W., Hai, F.I., Price, W.E., Guo, W., Ngo, H.H., Yamamoto, K., Nghiem, L.D. 2014. High retention membrane bioreactors: Challenges and opportunities. Bioresour. Technol. 167, 539-546.

Malik, R., Ramteke, D., Wate, S. 2006. Physico-chemical and surface characterization of adsorbent prepared from groundnut shell by $\mathrm{ZnCl}_{2}$ activation and its ability to absorb colour. Indian J. Chem. Technol. 13(4), 319-328.

Martins, A.C., Pezoti, O., Cazetta, A.L., Bedin, K.C., Yamazaki, D.A., Bandoch, G.F., Asefa, T., Visentainer, J.V., Almeida, V.C. 2015. Removal of tetracycline by $\mathrm{NaOH}$-activated carbon produced from macadamia nut shells: kinetic and equilibrium studies. Chem. Eng. J. 260, 291-299.

Mehrjouei, M., Müller, S., Möller, D. 2014. Energy consumption of three different advanced oxidation methods for water treatment: a cost-effectiveness study. J. Cleaner Prod. 65, 178183.

Méndez-Díaz, J., Prados-Joya, G., Rivera-Utrilla, J., Leyva-Ramos, R., Sánchez-Polo, M., FerroGarcía, M., Medellín-Castillo, N. 2010. Kinetic study of the adsorption of nitroimidazole antibiotics on activated carbons in aqueous phase. J. Colloid Interf. Sci. 345(2), 481-490.

Michael, I., Rizzo, L., McArdell, C. S., Manaia, C. M., Merlin, C., Schwartz, T., Dagot, C., Fatta-Kassinos, D. 2013. Urban wastewater treatment plants as hotspots for the release of antibiotics in the environment: a review. Water Res. 47(3), 957-995.

Mohammadi, A., Kazemipour, M., Ranjbar, H., Walker, R.B., Ansari, M. 2015. Amoxicillin removal from aqueous media using multi-walled carbon nanotubes. Fullerenes Nanotubes Carbon Nanostructures 23(2), 165-169. 
Mohan, D., Sarswat, A., Ok, Y.S., Pittman, C.U. 2014. Organic and inorganic contaminants removal from water with biochar, a renewable, low cost and sustainable adsorbent - a critical review. Bioresour. Technol. 160, 191-202.

Mompelat, S., Le Bot, B., Thomas, O. 2009. Occurrence and fate of pharmaceutical products and by-products, from resource to drinking water. Environ. Int. 35(5), 803-814.

Moussavi, G., Alahabadi, A., Yaghmaeian, K., Eskandari, M. 2013. Preparation, characterization and adsorption potential of the $\mathrm{NH} 4 \mathrm{Cl}$-induced activated carbon for the removal of amoxicillin antibiotic from water. Chem. Eng. J. 217, 119-128.

Nakagawa, K., Namba, A., Mukai, S.R., Tamon, H., Ariyadejwanich, P., Tanthapanichakoon, W. 2004. Adsorption of phenol and reactive dye from aqueous solution on activated carbons derived from solid wastes. Water Res. 38(7), 1791-1798.

Pan, B., Xing, B. 2008. Adsorption mechanisms of organic chemicals on carbon nanotubes. Environ. Sci. Technol. 42(24), 9005-9013.

Pei, Z., Shan, X.-Q., Kong, J., Wen, B., Owens, G. 2009. Coadsorption of ciprofloxacin and Cu (II) on montmorillonite and kaolinite as affected by solution pH. Environ. Sci. Technol. 44(3), 915-920.

Peng, X., Luan, Z., Chen, F., Tian, B., Jia, Z. 2005. Adsorption of humic acid onto pillared bentonite. Desalination 174(2), 135-143.

Pouretedal, H., Sadegh, N. 2014. Effective removal of Amoxicillin, Cephalexin, Tetracycline and Penicillin $\mathrm{G}$ from aqueous solutions using activated carbon nanoparticles prepared from vine wood. J. Water Process Eng. 1, 64-73.

Purnell, S., Ebdon, J., Buck, A., Tupper, M., Taylor, H. 2015. Bacteriophage removal in a fullscale membrane bioreactor (MBR) - implications for wastewater reuse. Water Res. 73, 109117. 
Putra, E.K., Pranowo, R., Sunarso, J., Indraswati, N., Ismadji, S. 2009. Performance of activated carbon and bentonite for adsorption of amoxicillin from wastewater: mechanisms, isotherms and kinetics. Water Res. 43(9), 2419-2430.

Qiang, Z., Adams, C. 2004. Potentiometric determination of acid dissociation constants (pK a) for human and veterinary antibiotics. Water Res. 38(12), 2874-2890.

Quist-Jensen, C., Macedonio, F., Drioli, E. 2015. Membrane technology for water production in agriculture: desalination and wastewater reuse. Desalination 364, 17-32.

Radovic, L.R., Moreno-Castilla, C., Rivera-Utrilla, J. 2001. Carbon materials as adsorbents in aqueous solutions. In Chemistry and Physics of Carbon, edited by Radovic, L.R. CRC Press, pp. 227-406.

Rajapaksha, A.U., Vithanage, M., Ahmad, M., Seo, D.-C., Cho, J.-S., Lee, S.-E., Lee, S.S., Ok, Y.S. 2015. Enhanced sulfamethazine removal by steam-activated invasive plant-derived biochar. J. Hazard. Mater. 290, 43-50.

Rajapaksha, A.U., Vithanage, M., Zhang, M., Ahmad, M., Mohan, D., Chang, S.X., Ok, Y.S. 2014. Pyrolysis condition affected sulfamethazine sorption by tea waste biochars. Bioresour. Technol. 166, 303-308.

Regmi, P., Moscoso, J.L.G., Kumar, S., Cao, X., Mao, J., Schafran, G. 2012. Removal of copper and cadmium from aqueous solution using switchgrass biochar produced via hydrothermal carbonization process. J. Environ. Manage. 109, 61-69.

Rivera-Utrilla, J., Prados-Joya, G., Sánchez-Polo, M., Ferro-García, M., Bautista-Toledo, I. 2009. Removal of nitroimidazole antibiotics from aqueous solution by adsorption/bioadsorption on activated carbon. J. Hazard. Mater. 170(1), 298-305.

Rizzo, L., Manaia, C., Merlin, C., Schwartz, T., Dagot, C., Ploy, M.C., Michael, I., FattaKassinos, D. 2013. Urban wastewater treatment plants as hotspots for antibiotic resistant bacteria and genes spread into the environment: a review. Sci. Total Environ. 447, 345-360. 
Rondon, H., El-Cheikh, W., Boluarte, I.A.R., Chang, C.-Y., Bagshaw, S., Farago, L., Jegatheesan, V., Shu, L. 2015. Application of enhanced membrane bioreactor (eMBR) to treat dye wastewater. Bioresour. Technol. 183, 78-85.

Roosta, M., Ghaedi, M., Daneshfar, A., Sahraei, R., Asghari, A. 2014a. Optimization of the ultrasonic assisted removal of methylene blue by gold nanoparticles loaded on activated carbon using experimental design methodology. Ultrason. Sonochem. 21(1), 242-252.

Roosta, M., Ghaedi, M., Shokri, N., Daneshfar, A., Sahraei, R., Asghari, A. 2014b. Optimization of the combined ultrasonic assisted/adsorption method for the removal of malachite green by gold nanoparticles loaded on activated carbon: experimental design. Spectrochim. Acta A Mol. Biomol. Spectrosc. 118, 55-65.

Sabio, E., Gonzalez, E., Gonzalez, J., González-Garcı, C., Ramiro, A., Ganan, J. 2004. Thermal regeneration of activated carbon saturated with p-nitrophenol. Carbon 42(11), 2285-2293.

Sapkota, A., Sapkota, A.R., Kucharski, M., Burke, J., McKenzie, S., Walker, P., Lawrence. 2008. Aquaculture practices and potential human health risks: current knowledge and future priorities. Environ. Int. 34, 1215-1226.

Sarmah, A.K., Meyer, M.T., Boxall, A.B. 2006. A global perspective on the use, sales, exposure pathways, occurrence, fate and effects of veterinary antibiotics (VAs) in the environment. Chemosphere 65, 725-759.

Schwarzenbach, R.P., Gschwend, P.M., Imboden, D.M. 2005. Environmental Organic Chemistry. John Wiley \& Sons.

Singh, R.K., Patel, K.D., Kim, J.-J., Kim, T.-H., Kim, J.-H., Shin, U.S., Lee, E.-J., Knowles, J.C., Kim, H.-W. 2014. Multifunctional hybrid nanocarrier: magnetic CNTs ensheathed with mesoporous silica for drug delivery and imaging system. ACS Appl. Mater. Interf. 6(4), 2201-2208.

Sköld, O. 2011. Antibiotics and Antibiotics Resistance. Wiley, New Jersey, 207 pp. 
Stackelberg, P.E., Gibs, J., Furlong, E.T., Meyer, M.T., Zaugg, S.D., Lippincott, R.L. 2007. Efficiency of conventional drinking-water-treatment processes in removal of pharmaceuticals and other organic compounds. Sci. Total Environ. 377(2), 255-272.

Tamon, H., Saito, T., Kishimura, M., Okazaki, M., Toei, R. 1990. Solvent regeneration of spent activated carbon in wastewater treatment. J. Chem. Eng. Japan 23(4), 426-432.

Tan, X., Liu, Y., Zeng, G., Wang, X., Hu, X., Gu, Y., Yang, Z. 2015. Application of biochar for the removal of pollutants from aqueous solutions. Chemosphere 125, 70-85.

Teixidó, M., Pignatello, J.J., Beltrán, J.L., Granados, M., Peccia, J. 2011. Speciation of the ionizable antibiotic sulfamethazine on black carbon (biochar). Environ. Sci. Technol. 45(23), 10020-10027.

Ternes, T.A. 1998. Occurrence of drugs in German sewage treatment plants and rivers. Water Res. 32(11), 3245-3260.

Thiele-Bruhn, S. 2003. Pharmaceutical antibiotic compounds in soils - a review. J. Plant Nutrition Soil Sci. 166(2), 145-167.

Thiele-Bruhn, S., Seibicke, T., Schulten, H.-R., Leinweber, P. 2004. Sorption of sulfonamide pharmaceutical antibiotics on whole soils and particle-size fractions. J. Environ. Quality. 33(4), 1331-1342.

Tian, Y., Gao, B., Morales, V.L., Chen, H., Wang, Y., Li, H. 2013. Removal of sulfamethoxazole and sulfapyridine by carbon nanotubes in fixed-bed columns. Chemosphere 90(10), 2597-2605.

Tolls, J. 2001. Sorption of veterinary pharmaceuticals in soils: a review. Environ. Sci. Technol. 35(17), 3397-3406.

Toor, M., Jin, B. 2012. Adsorption characteristics, isotherm, kinetics, and diffusion of modified natural bentonite for removing diazo dye. Chem. Eng. J. 187, 79-88.

Torres-Pérez, J., Gérente, C., Andrès, Y. 2012. Sustainable activated carbons from agricultural residues dedicated to antibiotic removal by adsorption. Chin. J. Chem. Eng. 20(3), 524-529. 
Uchimiya, M., Bannon, D.I., Wartelle, L.H. 2012. Retention of heavy metals by carboxyl functional groups of biochars in small arms range soil. J. Agricul. Food Chem. 60(7), 17981809.

Üstün, G.E., Solmaz, S.K.A., Birgül, A. 2007. Regeneration of industrial district wastewater using a combination of Fenton process and ion exchange - A case study. Resour. Conserv. Recy. 52(2), 425-440.

Vargas, A.M., Cazetta, A.L., Kunita, M.H., Silva, T.L., Almeida, V.C. 2011. Adsorption of methylene blue on activated carbon produced from flamboyant pods (Delonix regia): study of adsorption isotherms and kinetic models. Chem. Eng. J. 168(2), 722-730.

Wang, L.K., Hung, Y.-T., Shammas, N.K. 2007. Advanced Physicochemical Treatment Technologies. Springer.

Wang, Y., Huang, C., Xu, T. 2011. Which is more competitive for production of organic acids, ion-exchange or electrodialysis with bipolar membranes? J. Membrane Sci. 374(1), 150-156.

Watkinson, A., Murby, E., Costanzo, S. 2007. Removal of antibiotics in conventional and advanced wastewater treatment: implications for environmental discharge and wastewater recycling. Water Res. 41(18), 4164-4176.

Wollenberger, L., Halling-Sørensen, B., Kusk, K.O. 2000. Acute and chronic toxicity of veterinary antibiotics to Daphnia magna. Chemosphere 40, 723-730.

Xie, M., Chen, W., Xu, Z., Zheng, S., Zhu, D. 2014. Adsorption of sulfonamides to demineralized pine wood biochars prepared under different thermochemical conditions. Environ. Pollut. 186, 187-194.

Xing, B., Pignatello, J.J., Gigliotti, B. 1996. Competitive sorption between atrazine and other organic compounds in soils and model sorbents. Environ. Sci. Technol. 30(8), 2432-2440.

Xu, X., Cao, X., Zhao, L. 2013. Comparison of rice husk-and dairy manure-derived biochars for simultaneously removing heavy metals from aqueous solutions: role of mineral components in biochars. Chemosphere 92(8), 955-961. 
Xue, Y., Gao, B., Yao, Y., Inyang, M., Zhang, M., Zimmerman, A.R., Ro, K.S. 2012. Hydrogen peroxide modification enhances the ability of biochar (hydrochar) produced from hydrothermal carbonization of peanut hull to remove aqueous heavy metals: batch and column tests. Chem. Eng. J. 200, 673-680.

Yan, C., Yang, Y., Zhou, J., Liu, M., Nie, M., Shi, H., Gu, L. 2013a. Antibiotics in the surface water of the Yangtze Estuary: occurrence, distribution and risk assessment. Environ. Pollut. $175,22-29$.

Yan, W., Zhang, J., Jing, C. 2013b. Adsorption of enrofloxacin on montmorillonite: twodimensional correlation ATR/FTIR spectroscopy study. J. Colloid Interf. Sci. 390(1), 196203.

Yang, J. F., Ying, G. G., Zhao, J. L., Tao, R., Su, H. C., \& Liu, Y. S. 2011. Spatial and seasonal distribution of selected antibiotics in surface waters of the Pearl Rivers, China. J. Environ. Sci. Health Part B 46(3), 272-280.

Yang, Y., Wei, Z., Zhang, X., Chen, X., Yue, D., Yin, Q., Xiao, L., Yang, L. 2014. Biochar from alternanthera philoxeroides could remove $\mathrm{Pb}$ (II) efficiently. Bioresour. Technol. 171, 227232.

Yao, Y., Gao, B., Chen, H., Jiang, L., Inyang, M., Zimmerman, A.R., Cao, X., Yang, L., Xue, Y., Li, H. 2012. Adsorption of sulfamethoxazole on biochar and its impact on reclaimed water irrigation. J. Hazard. Mater. 209, 408-413.

Zhang, G., Liu, X., Sun, K., He, Q., Qian, T., Yan, Y. 2013. Interactions of simazine, metsulfuron-methyl, and tetracycline with biochars and soil as a function of molecular structure. J. Soils Sed. 13(9), 1600-1610.

Zhang, G., Zhang, Q., Sun, K., Liu, X., Zheng, W., Zhao, Y. 2011. Sorption of simazine to corn straw biochars prepared at different pyrolytic temperatures. Environ. Pollut. 159(10), 25942601. 
Zhang, L., Shi, S., Dong, L., Zhang, T., Zhou, L., Huang, Y. 2011. Concentrations and possible sources of polychlorinated biphenyls in the surface water of the Yangtze River Delta, China. Chemosphere 85(3), 399-405.

Zhang, M., Gao, B., Yao, Y., Xue, Y., Inyang, M. 2012. Synthesis of porous MgO-biochar nanocomposites for removal of phosphate and nitrate from aqueous solutions. Chem. Eng. J. 210, 26-32.

Zheng, H., Wang, Z., Zhao, J., Herbert, S., Xing, B. 2013. Sorption of antibiotic sulfamethoxazole varies with biochars produced at different temperatures. Environ. Pollut. 181, 60-67.

Zheng, W., Guo, M., Chow, T., Bennett, D.N., Rajagopalan, N. 2010. Sorption properties of greenwaste biochar for two triazine pesticides. J. Hazard. Mater. 181(1), 121-126.

Zhou, Q., Li, Z., Shuang, C., Li, A., Zhang, M., Wang, M. 2012. Efficient removal of tetracycline by reusable magnetic microspheres with a high surface area. Chem. Eng. J. 210, 350-356. 
Table 1

Physicochemical properties of major types of antibiotics investigated by different studies.

\begin{tabular}{|c|c|c|c|c|c|c|c|c|}
\hline Class & Compound & Acronym & CAS number & $\log k_{\text {ow }}$ & $\mathrm{p} K_{a}$ & Molecular mass & Molecular formula & Reference \\
\hline \multirow{3}{*}{$\begin{array}{l}\text { Chloramphenicols } \\
\text { (CPs) }\end{array}$} & Chloramphenicol & CAP & $56-75-7$ & 1.14 & & 323.13 & $\mathrm{C}_{12} \mathrm{H}_{12} \mathrm{Cl}_{2} \mathrm{~N}_{2} \mathrm{O}_{5}$ & \multirow[t]{3}{*}{ Yan et al. (2013a) } \\
\hline & Thiamphenicol & TAP & $15318-45-3$ & -0.27 & & 356.22 & $\mathrm{C}_{12} \mathrm{H}_{15} \mathrm{Cl}_{2} \mathrm{NO}_{5} \mathrm{~S}$ & \\
\hline & Florfenicol & $\mathrm{FF}$ & $76639-94-6$ & 0.37 & & 358.21 & $\mathrm{C}_{12} \mathrm{H}_{14} \mathrm{Cl}_{2} \mathrm{FNO}_{4}$ & \\
\hline \multirow[t]{2}{*}{ Macrolides (MLs) } & Erythromycin & ETM & 59319-72-1 & 3.06 & 8.9 & 731.95 & $\mathrm{C}_{38} \mathrm{H}_{69} \mathrm{NO}_{12}$ & \multirow[t]{2}{*}{ Yan et al. (2013a) } \\
\hline & Roxithromycin & RTM & 80214-83-1 & 2.75 & 9.17 & 837.05 & $\mathrm{C}_{41} \mathrm{H}_{76} \mathrm{~N}_{2} \mathrm{O}_{15}$ & \\
\hline \multirow[t]{6}{*}{ Sulfonamides (SAs) } & Sulfadiazine & SD & $68-35-9$ & -0.34 & $2.0 / 6.48$ & 250.28 & $\mathrm{C}_{10} \mathrm{H}_{10} \mathrm{~N}_{4} \mathrm{O}_{2} \mathrm{~S}$ & \multirow{6}{*}{$\begin{array}{l}\text { Qiang and Adams (2004), } \\
\text { Yan et al. (2013a), } \\
\text { Yang et al. (2011) }\end{array}$} \\
\hline & Sulfamerazine & SM & $127-79-7$ & 0.44 & $2.06 / 6.90$ & 264.30 & $\mathrm{C}_{11} \mathrm{H}_{12} \mathrm{~N}_{4} \mathrm{O}_{2} \mathrm{~S}$ & \\
\hline & Sulfamethazine & SMT & $57-68-1$ & 0.14 & $2.65 / 7.65$ & 278.34 & $\mathrm{C}_{12} \mathrm{H}_{14} \mathrm{~N}_{4} \mathrm{O}_{2} \mathrm{~S}$ & \\
\hline & Sulfamethoxazole & SMX & $723-46-6$ & 0.89 & $1.6 / 5.7$ & 253.28 & $\mathrm{C}_{10} \mathrm{H}_{11} \mathrm{~N}_{3} \mathrm{O}_{3} \mathrm{~S}$ & \\
\hline & Sulfathiazole & ST & $72-14-0$ & 0.05 & $2.2 / 7.24$ & 255.32 & $\mathrm{C}_{9} \mathrm{H}_{9} \mathrm{~N}_{3} \mathrm{O}_{2} \mathrm{~S}$ & \\
\hline & Sulfapyridine & SP & $144-83-2$ & 0.35 & $2.9 / 8.54$ & 249.29 & $\mathrm{C}_{11} \mathrm{H}_{11} \mathrm{~N}_{3} \mathrm{O}_{2} \mathrm{~S}$ & \\
\hline \multirow[t]{4}{*}{ Tetracyclines (TCs) } & Tetracycline & $\mathrm{TC}$ & $60-54-8$ & -1.37 & 3.3 & 444.43 & $\mathrm{C}_{22} \mathrm{H}_{24} \mathrm{~N}_{2} \mathrm{O}_{8} \cdot \mathrm{HCl}$ & \multirow[t]{4}{*}{$\begin{array}{l}\text { Qiang and Adams (2004), } \\
\text { Yan et al. (2013a), } \\
\text { Yang et al. (2011) }\end{array}$} \\
\hline & Chlortetracycline & CTC & $64-72-2$ & $\mathrm{n} / \mathrm{a}$ & $3.3 / 7.55$ & 515.34 & $\mathrm{C}_{22} \mathrm{H}_{23} \mathrm{ClN}_{2} \mathrm{O}_{8} \cdot \mathrm{HCl}$ & \\
\hline & Oxytetracycline & OTC & $2058-46-0$ & -0.9 & 9.5 & 496.90 & $\mathrm{C}_{22} \mathrm{H}_{24} \mathrm{~N}_{2} \mathrm{O}_{8} \cdot \mathrm{HCl}$ & \\
\hline & Doxycyclinehyclate & DXC & $24390-14-5$ & 2.37 & $3.02 / 7.97$ & 544.98 & $\mathrm{C}_{22} \mathrm{H}_{24} \mathrm{~N}_{2} \mathrm{O}_{9} \cdot \mathrm{HCl}$ & \\
\hline \multirow[t]{4}{*}{ Flouroquinolones (FQs) } & Norfloxacin & NFC & $70458-96-7$ & -0.46 & $3.11 / 6.10$ & 319.33 & $\mathrm{C}_{16} \mathrm{H}_{18} \mathrm{FN}_{3} \mathrm{O}_{3}$ & \multirow{4}{*}{$\begin{array}{l}\text { Qiang and Adams (2004), } \\
\text { Yang et al. (2011) }\end{array}$} \\
\hline & Enrofloxacin & $\mathrm{EFC}$ & $93106-60-6$ & 0.70 & $3.85 / 6.19$ & 359.4 & $\mathrm{C}_{19} \mathrm{H}_{22} \mathrm{FN}_{3} \mathrm{O}_{3}$ & \\
\hline & Ciprofloxacin & CIP & $85721-33-1$ & 0.28 & 6.09 & 331.34 & $\mathrm{C}_{17} \mathrm{H}_{18} \mathrm{FN}_{3} \mathrm{O}_{3}$ & \\
\hline & Ofloxacin & OFC & $82419-36-1$ & -0.02 & & 331.34 & $\mathrm{C}_{18} \mathrm{H}_{20} \mathrm{FN}_{3} \mathrm{O}_{3}$ & \\
\hline Imidazoles & $\begin{array}{l}\text { Metronidazole, fenbendazole, } \\
\text { oxfendazole }\end{array}$ & & & $-0.02-3.9$ & 2.4 & $171.5-315.3$ & & Thiele-Bruhn (2003) \\
\hline$\beta$-Lactams & $\begin{array}{l}\text { Penicillins, ampicillin, } \\
\text { meropenem, cephalosporins, } \\
\text { ceftiofur, penicillin G, cefotianm }\end{array}$ & & & $0.9-2.9$ & 2.7 & $334.4-470.3$ & & Thiele-Bruhn (2003) \\
\hline \multirow[t]{3}{*}{ Others } & Carbadox & CARB & $6804-07-5$ & & & 262.2 & $\mathrm{C}_{11} \mathrm{H}_{10} \mathrm{~N}_{4} \mathrm{O}_{4}$ & \multirow[t]{3}{*}{ Qiang and Adams (2004) } \\
\hline & Lincomycin & LNCM & $859-18-7$ & & 7.80 & 443.0 & $\mathrm{C}_{18} \mathrm{H}_{34} \mathrm{~N}_{2} \mathrm{O}_{6} \mathrm{~S} \cdot \mathrm{HCl}$ & \\
\hline & Trimethoprim & TRMP & $738-70-5$ & & $3.24 / 6.76$ & 290.3 & $\mathrm{C}_{14} \mathrm{H}_{18} \mathrm{~N}_{4} \mathrm{O}_{3}$ & \\
\hline
\end{tabular}


Table 2

Summary of the antibiotic removal by AC adsorbents applied in the treatment of contaminated water.

\begin{tabular}{|c|c|c|c|c|}
\hline Antibiotic class/compound & Adsorbate concentration (mg/L) & Operating condition & Removal & Reference \\
\hline \multirow[t]{3}{*}{$\beta$-Lactams/amoxicillin } & 300 & $\mathrm{pH} 2-7,0.1-3.5 \mathrm{~g} \mathrm{AC}, 30^{\circ} \mathrm{C}$ & $95 \%$ & Putra et al. (2009) \\
\hline & 50 & $0.4 \mathrm{~g} / \mathrm{L} \mathrm{PAC}, \mathrm{pH} 6,>50{ }^{\circ} \mathrm{C}$ & $99 \%$ & Moussavi et al. (2013) \\
\hline & 20 & $\mathrm{pH} 2,45^{\circ} \mathrm{C}, 0.4 \mathrm{~g} / \mathrm{L} \mathrm{AC}$, time $8 \mathrm{~h}$ & $74-88 \%$ & Pouretedal and Sadegh (2014) \\
\hline Cephalexin & 20 & $\mathrm{pH} 2,45^{\circ} \mathrm{C}, 0.4 \mathrm{~g} / \mathrm{L} \mathrm{AC}$, time $=8 \mathrm{~h}$ & $74-88 \%$ & Pouretedal and Sadegh (2014) \\
\hline Imidazoles/nitroimidazoles & $100-600$ & $25^{\circ} \mathrm{C}, \mathrm{pH} 2-11$ & & Rivera-Utrilla et al. (2009) \\
\hline Dimetridazole & & $0-0.1 \mathrm{M} \mathrm{NaCl}, 1 \mathrm{~g} / \mathrm{L} \mathrm{AC}$ & & \\
\hline \multicolumn{5}{|l|}{ Metronidazole } \\
\hline Ronidazole & 150 & $25^{\circ} \mathrm{C}, 0.2-1 \mathrm{~g} / \mathrm{L} \mathrm{AC}, \mathrm{pH} 7$ & $90 \%$ & Méndez-Díaz et al. (2010) \\
\hline \multicolumn{5}{|l|}{ Tinidazole } \\
\hline \multirow[t]{2}{*}{ Penicillins/penicillin G } & 20 & $\mathrm{pH} 2,45^{\circ} \mathrm{C}, 0.4 \mathrm{~g} / \mathrm{L} \mathrm{AC}$, time $8 \mathrm{~h}$ & $74-88 \%$ & Pouretedal and Sadegh (2014) \\
\hline & 50 & pH 6, batch process, $25^{\circ} \mathrm{C}$, time $48-72 \mathrm{~h}$ & & Ania et al. (2011) \\
\hline Quinoxaline derivatives/carbadox & 50 & Time 4 h, 0.66 g PAC, pH 7 & $>90 \%$ & Adams et al. (2002) \\
\hline Sulphonamides/sulfamerazine & 50 & Time 4 h, 0.66 g PAC, pH 7 & $>90 \%$ for PAC & Adams et al. (2002) \\
\hline \multicolumn{5}{|l|}{ Sulfamethazine } \\
\hline \multicolumn{5}{|l|}{ Sulfathiazole } \\
\hline \multicolumn{5}{|l|}{ Sulfachlorpyridazine } \\
\hline \multicolumn{5}{|l|}{ Sulfadimethoxine } \\
\hline Sulfamethoxazole & & Time $1.5-3 \mathrm{~min}$ & $100 \%$ & Stackelberg et al. (2007) \\
\hline Ciprofloxacin & $20-40$ & Batch: $22^{\circ} \mathrm{C}, \mathrm{pH}<5.5,0.0125 \mathrm{~g} \mathrm{GAC}$ & $87 \%$ & Genç and Dogan (2015) \\
\hline \multirow[t]{3}{*}{ Tetracycline } & $50,100,300$ & Batch, time $120 \mathrm{~h}, \mathrm{pH} 3.4-11$ & & Torres-Pérez et al. (2012) \\
\hline & 20 & $\mathrm{pH} 2,45^{\circ} \mathrm{C}, 0.4 \mathrm{~g} / \mathrm{L} \mathrm{AC}$, time $8 \mathrm{~h}$ & $74-88 \%$ & Pouretedal and Sadegh (2014) \\
\hline & 600 & $\mathrm{pH} 3-10$ & & Martins et al. (2015) \\
\hline \multirow[t]{2}{*}{ Trimethoprim } & 50 & Time 4 h, 0.66 g PAC, pH 7 & $>90 \%$ by PAC & Adams et al. (2002) \\
\hline & 50 & $\mathrm{pH} 4-10,25^{\circ} \mathrm{C}, 0-3 \mathrm{~g} / \mathrm{L} \mathrm{AC}$ & $>90 \%$ & Kim et al. (2010) \\
\hline
\end{tabular}


Table 3

Summary of antibiotic removal process by CNTs applied in the treatment of contaminated water.

\begin{tabular}{|c|c|c|c|c|}
\hline Antibiotic class/compound & Adsorbate concentration (mg/L) & Operating condition & Removal & Reference \\
\hline$\beta$-Lactams/amoxicillin & 80 & Batch: $0.1-0.2 \mathrm{~g}$ MWCNT, pH 4.6, time $120 \mathrm{~h}$ & $86.5 \%$ & Mohammadi et al. (2015) \\
\hline Lincosamides/lincomycin & 12,000 & Batch: $20^{\circ} \mathrm{C}, \mathrm{pH} 6.0$, time $100 \mathrm{~h}$ & $>90 \%$ & Kim et al. (2014a) \\
\hline Sulphonamides/sulfamethoxazole & 12,000 & Batch: $20^{\circ} \mathrm{C}, \mathrm{pH} 6.0$, time $100 \mathrm{~h}$ & $>90 \%$ & Kim et al. (2014a) \\
\hline Sulfamethoxazole & 200 & Fixed bed column: $\mathrm{pH} 3.0-9.0$, time $2 \mathrm{~h}$ & $96 \%$ & Tian et al. (2013) \\
\hline Sulfapyridine & & & & \\
\hline $\begin{array}{l}\text { Sulfamethoxazole } \\
\text { Sulfapyridine }\end{array}$ & $0.21-2.50$ & Batch: 15 mg MWCNT, pH 5.7-6.2 & $80 \%$ & Ji et al. (2009b) \\
\hline
\end{tabular}

\section{Table 4}

Summary of antibiotic removal by clay material (bentonite) applied in the treatment of contaminated water.

\begin{tabular}{|c|c|c|c|c|}
\hline Antibiotic class/compound & Adsorbate concentration $(\mathrm{mg} / \mathrm{L})$ & Operating condition & Removal & Reference \\
\hline$\beta$-Lactams/amoxicillin & 300 & $\mathrm{pH} 2-7,0.1-3.5 \mathrm{~g}$ adsorbent, $30^{\circ} \mathrm{C}$ & $88 \%$ & Putra et al. (2009) \\
\hline \multirow{2}{*}{ Flouroquinolones/ciprofloxacin (CIP) } & $50-500$ & Batch: contact time $30 \mathrm{~min}, \mathrm{pH} 4.5,2.5 \mathrm{~g} / \mathrm{L}$ bentonite & $99 \%$ & Genç et al. (2013) \\
\hline & $20-40$ & Batch, $22{ }^{\circ} \mathrm{C}, \mathrm{pH}<5.5,0.0125 \mathrm{~g}$ adsorbent & $87-91 \%$ & Genç and Dogan (2015) \\
\hline
\end{tabular}


Table 5

Summary of antibiotic removal by ion exchange resins applied in the treatment of contaminated water.

\begin{tabular}{|c|c|c|c|c|}
\hline Antibiotic class/compound & Adsorbate concentration $(\mathrm{mg} / \mathrm{L})$ & Operating condition & Removal & Reference \\
\hline $\begin{array}{l}\text { Sulphonamides/sulfachloropyridazine } \\
\text { Sulfadimethoxine } \\
\text { Sulfamerazine } \\
\text { Sulfamethazine } \\
\text { Sulfamethoxazole } \\
\text { Sulfamonomethoxine } \\
\text { Sulfathiazole }\end{array}$ & 10 & $\begin{array}{l}\mathrm{pH} 7.0,25^{\circ} \mathrm{C} \text {, time } 15 \mathrm{~d} \\
\text { MIEX }^{@} \text { resin treatment: } \mathrm{pH} 7.0,25^{\circ} \mathrm{C} \text {, } \\
0.5-5.0 \mathrm{~mL} / \mathrm{L} \text { resin, time } 24 \mathrm{~h}\end{array}$ & $\sim 90 \%$ & Choi et al. (2007) \\
\hline $\begin{array}{l}\text { Sulfamerazine } \\
\text { Sulfamethazine } \\
\text { Sulfathiazole } \\
\text { Sulfachloropyridazine } \\
\text { Sulfadimethoxine }\end{array}$ & 50 & Time $4 \mathrm{~h}, 0.66 \mathrm{~g}$ ion exchange resins, $\mathrm{pH} 7$ & $>90 \%$ for $P A C$ & Adams et al. (2002) \\
\hline $\begin{array}{l}\text { Sulfamethazine } \\
\text { Sulfamethoxazole } \\
\text { Sulfamethazine }\end{array}$ & $\begin{array}{l}200-400 \\
30-350\end{array}$ & $\begin{array}{l}\text { Fixed bed: room temp., } 1.3 \mathrm{~g} \text { resin, time } 100 \mathrm{~min} \\
\text { Batch and continuous, time } 120 \mathrm{~min}\end{array}$ & $100 \%$ & $\begin{array}{l}\text { Fernández et al. (2014b) } \\
\text { Fernández et al. (2014a) }\end{array}$ \\
\hline Quinoxaline derivatives/carbadox & 50 & $\begin{array}{l}0.66 \mathrm{~g} \text { strong-acid cation and strong-base anion } \\
\text { resins, } \mathrm{pH} 7\end{array}$ & & Adams et al. (2002) \\
\hline $\begin{array}{l}\text { Tetracyclines/chlortetracycline } \\
\text { Democycline } \\
\text { Doxycycline } \\
\text { Meclocycline } \\
\text { Minocycline } \\
\text { Oxytetracycline } \\
\text { Tetracycline }\end{array}$ & 10 & $\mathrm{pH} 7.0,25^{\circ} \mathrm{C}$, time $1 \mathrm{~d}$ and $15 \mathrm{~d}, 0.5-5.0 \mathrm{~mL} / \mathrm{L}$ resin & $>80 \%$ & Choi et al. (2007) \\
\hline Trimethoprim & 50 & Sorption: time $4 \mathrm{~h}, 0.66 \mathrm{~g}$ ion exchange resins, $\mathrm{pH} 7$ & & Adams et al. (2002) \\
\hline
\end{tabular}


Table 6

Summary of antibiotic removal by $\mathrm{BC}$ adsorbents applied in the treatment of contaminated water.

\begin{tabular}{|c|c|c|c|c|}
\hline Antibiotic & Adsorbate concentration $(\mathrm{mg} / \mathrm{L})$ & Operating condition & Removal & Reference \\
\hline Amphenicol/ florfenicol & 50 & Batch: $0.4 \mathrm{~g} \mathrm{BC}, 22^{\circ} \mathrm{C}$, time $24 \mathrm{~h}$ & $100 \%$ & Mitchell et al. (2015) \\
\hline Ceftiofur & 50 & Batch: $0.4 \mathrm{~g} \mathrm{BC}, 22^{\circ} \mathrm{C}$, time $24 \mathrm{~h}$ & $98-100 \%$ & Mitchell et al. (2015) \\
\hline \multirow[t]{2}{*}{ Sulfamethoxazole } & 12.5 & Batch: 35 rpm, time 72 h, pH 5 & & Zheng et al. (2013) \\
\hline & 10 & $0.1 \mathrm{~g} \mathrm{BC}, 22 \pm 0.5^{\circ} \mathrm{C}$ & & Yao et al. (2012) \\
\hline Sulfamethazine & $0.001-0.1$ & $\mathrm{pH} 5,48 \mathrm{~h}, 20 \pm 0.2^{\circ} \mathrm{C}$ & & Teixidó et al. (2011) \\
\hline Sulfamethoxazole & 50 & Batch: $10-15$ mg BC, pH 6 & & Xie et al. (2014) \\
\hline \multicolumn{5}{|l|}{ Sulfapyridine } \\
\hline Tetracycline & $50-1000$ & $0.1 \mathrm{~g} \mathrm{BC}, 30^{\circ} \mathrm{C}$ & & Liu et al. (2012) \\
\hline
\end{tabular}


Table 7a

Model parameters for the equilibrium isotherms and kinetics of adsorptive materials during antibiotic removal from contaminated water.

\begin{tabular}{|c|c|c|c|c|c|c|c|c|c|c|c|c|c|c|}
\hline \multirow[t]{3}{*}{ Antibiotic } & \multirow[t]{3}{*}{ Adsorbent } & \multicolumn{6}{|c|}{ Equilibrium model } & \multicolumn{6}{|c|}{ Kinetic model } & \multirow[t]{3}{*}{ Reference } \\
\hline & & \multicolumn{3}{|c|}{ Langmuir parameters } & \multicolumn{3}{|c|}{ Freundlich parameters } & \multicolumn{3}{|c|}{ Pseudo 1st order } & \multicolumn{3}{|c|}{ Pseudo 2nd order } & \\
\hline & & $\mathrm{q}_{\max }$ & $\mathrm{b}_{\mathrm{L}}$ & $r^{2}$ & $\mathrm{n}$ & $\mathrm{K}_{\mathrm{F}}$ & $r^{2}$ & $\overline{\mathrm{q}_{\mathrm{e}}}$ & $\mathrm{k}_{1}$ & $r^{2}$ & $\overline{\mathrm{q}_{\mathrm{e}}}$ & $\mathrm{k}_{2}$ & $r^{2}$ & \\
\hline Sulfamethazole & $\mathrm{BC} 500 \mathrm{H}$ & & & & $0.20 \pm 0.01$ & $0.164 \pm 0.009$ & 0.98 & & & & & & & Xie et al. (2014) \\
\hline Sulfapyridine & & & & & $0.16 \pm 0.01$ & $0.143 \pm 0.008$ & 0.96 & & & & & & & \\
\hline \multirow{9}{*}{$\begin{array}{l}\text { Sulfamethazole } \\
\text { (SMX) }\end{array}$} & BC500 & & & & $0.256 \pm 0.012$ & $2.54 \pm 0.0197$ & 0.952 & & & & & & & Zheng et al. (2013) \\
\hline & BC600 & & & & $0.198 \pm 0.011$ & $2.94 \pm 0.0106$ & 0.955 & & & & & & & \\
\hline & WBC & $118 \pm 5$ & & 0.982 & $3.1 \pm 0.2$ & $0.308 \pm 0.008$ & 0.987 & 111 & 0.15 & 0.978 & 118 & 0.0021 & 0.991 & Calisto et al. (2015) \\
\hline & SWCNT & & & & $0.31 \pm 0.06$ & $6.38 \pm 2.91$ & 0.931 & & & & & & & Kim et al. (2014a) \\
\hline & MWCNT & & & & $0.48 \pm 0.05$ & $2.01 \pm 0.51$ & 0.986 & & & & & & & \\
\hline & PAC & & & & $0.30 \pm 0.02$ & $3.78 \pm 0.46$ & 0.993 & & & & & & & \\
\hline & SWCNT & & & & $0.40 \pm 0.01$ & $5.2 \pm 0.400$ & 0.992 & & & & & & & Ji et al. (2010) \\
\hline & MWCNT & & & & $0.347 \pm 0.007$ & $2.3 \pm 0.100$ & 0.996 & & & & & & & \\
\hline & Anion Exchange & 263 & 0.017 & 0.997 & & & & & & & & & & $\begin{array}{l}\text { Fernández et al. } \\
\text { (2014a) }\end{array}$ \\
\hline \multirow[t]{2}{*}{$\begin{array}{l}\text { Sulfamethazine } \\
\quad(\mathrm{SMZ})\end{array}$} & Anion Exchange & 110 & 0.043 & 0.981 & & & & & & & & & & $\begin{array}{l}\text { Fernández et al. } \\
\text { (2014b) }\end{array}$ \\
\hline & & 110 & 0.043 & 0.995 & & & & & & & & & & $\begin{array}{l}\text { Fernández et al. } \\
\text { (2014a) }\end{array}$ \\
\hline \multirow[t]{10}{*}{ Tetracycline } & SWCNT & & & & $0.095 \pm 0.004$ & $1.4 \pm 0.300$ & 0.976 & & & & & & & Ji et al. (2010) \\
\hline & MWCNT & & & & $0.104 \pm 0.005$ & $0.800 \pm 0.020$ & 0.977 & & & & & & & \\
\hline & $\mathrm{BP}-\mathrm{H}_{2} \mathrm{O}$ & 288.3 & 0.2075 & 0.990 & 0.15 & 0.30465 & 1.000 & & & & & & & Torres-Pérez et al. \\
\hline & $\mathrm{PH}-\mathrm{H}_{2} \mathrm{O}$ & 28.0 & 1.5393 & 0.972 & 0.10 & 0.0418 & 0.985 & & & & & & & $(2012)$ \\
\hline & GAC1 & 133.1 & 0.0533 & 0.998 & 0.21 & 0.09607 & 0.999 & & & & & & & \\
\hline & GAC2 & 816.7 & 1.7809 & 0.987 & 0.10 & 1.2033 & 0.999 & & & & & & & \\
\hline & $\mathrm{BP}-\mathrm{H}_{2} \mathrm{O}$ & 308.8 & 0.0621 & 0.929 & 0.29 & 0.15457 & 0.969 & & & & & & & \\
\hline & GAC2 & 549.5 & 1.0944 & 0.990 & 0.06 & 0.9535 & 0.995 & & & & & & & \\
\hline & $\mathrm{AC}$ & 1.98 & 1.87 & 0.980 & & 0.54 & 0.960 & & 0.002 & 0.910 & & 0.233 & 0.990 & $\begin{array}{l}\text { Pouretedal and } \\
\text { Sadegh (2014) }\end{array}$ \\
\hline & $\mathrm{NaOH}-\mathrm{AC}$ & 455.8 & & 0.97 & 14.63 & 0.7769 & 0.970 & 381.9 & 0.204 & 0.89 & 408.3 & 0.00073 & 0.960 & Martins et al. (2015) \\
\hline
\end{tabular}


Table 7b

Model parameters for the equilibrium isotherms and kinetics of adsorptive materials during antibiotic removal from contaminated water.

\begin{tabular}{|c|c|c|c|c|c|c|c|c|c|c|c|c|c|c|}
\hline \multirow[t]{3}{*}{ Antibiotic } & \multirow[t]{3}{*}{ Adsorbent } & \multicolumn{6}{|c|}{ Equilibrium model } & \multicolumn{6}{|c|}{ Kinetic model } & \multirow[t]{3}{*}{ Reference } \\
\hline & & \multicolumn{3}{|c|}{ Langmuir parameters } & \multicolumn{3}{|c|}{ Freundlich parameters } & \multicolumn{3}{|c|}{ Pseudo 1st order } & \multicolumn{3}{|c|}{ Pseudo 2nd order } & \\
\hline & & $\mathrm{q}_{\max }$ & $\mathrm{b}_{\mathrm{L}}$ & $r^{2}$ & $\mathrm{n}$ & $\mathrm{K}_{\mathrm{F}}$ & $r^{2}$ & $\mathrm{q}_{\mathrm{e}}$ & $\mathrm{k}_{1}$ & $r^{2}$ & $\mathrm{q}_{\mathrm{e}}$ & $\mathrm{k}_{2}$ & $r^{2}$ & \\
\hline \multirow[t]{6}{*}{$\begin{array}{l}\text { Amoxicillin } \\
\text { (AMX) }\end{array}$} & MWCNT & 23.458 & $2.50 \mathrm{e}-5$ & 0.999 & 0.3749 & 3.000 & 0.918 & & & & & & & $\begin{array}{l}\text { Mohammadi et al. } \\
\text { (2015) }\end{array}$ \\
\hline & SAC & 261.8 & 0.166 & 0.998 & 4.95 & 0.2448 & 0.96 & 83.3 & 0.044 & 0.983 & 125 & 0.001 & 0.998 & \multirow{5}{*}{$\begin{array}{l}\text { Moussavi et al. } \\
\text { (2013) } \\
\text { Pouretedal and } \\
\text { Sadegh (2014) } \\
\text { Putra et al. (2009) }\end{array}$} \\
\hline & NAC & 438.6 & 0.128 & 0.994 & 2.7 & 0.2086 & 0.959 & 40.29 & 0.099 & 0.961 & 126.6 & 0.013 & 0.999 & \\
\hline & $\mathrm{AC}$ & 7.367 & 2.51 & 0.980 & & 0.54 & 0.900 & & 0.005 & 0.890 & & 0.009 & 0.980 & \\
\hline & Bentonite & 53.93 & & 0.988 & & 0.0044 & 0.965 & 19.55 & 0.009 & 0.979 & 20.82 & 5.243 & 0.993 & \\
\hline & $\mathrm{AC}$ & 221.868 & & 0.994 & & 0.0336 & 0.9905 & 24.29 & 0.229 & 0.988 & 26.71 & 0.021 & 0.998 & \\
\hline Cephalexin & $A C$ & 7.08 & 1.08 & 0.980 & & 0.11 & 0.910 & & 0.004 & 0.890 & & 0.017 & 0.990 & Pouretedal and \\
\hline Penicillin G & $\mathrm{AC}$ & 8.41 & 3.10 & 0.990 & & 0.89 & 0.910 & & 0.004 & 0.910 & & 0.094 & 0.990 & Sadegh (2014) \\
\hline $\begin{array}{l}\text { Lincomycine } \\
\text { (LCN) }\end{array}$ & $\begin{array}{l}\text { SWCNT } \\
\text { MWCNT } \\
\text { PAC }\end{array}$ & & & & $\begin{array}{l}0.22 \pm 0.02 \\
0.35 \pm 0.03 \\
0.27 \pm 0.03\end{array}$ & $\begin{array}{l}1.03 \pm 0.17 \\
0.287 \pm 0.049 \\
1.00 \pm 0.18\end{array}$ & $\begin{array}{l}0.985 \\
0.987 \\
0.968\end{array}$ & & & & & & & Kim et al. (2014a) \\
\hline Nitroimidazole & $\mathrm{AC}$ & 287.532 & 0.0235 & $>0.999$ & & 1.451 & 0.932 & & & & & & & \multirow{4}{*}{$\begin{array}{l}\text { Rivera-Utrilla et al. } \\
\text { (2009) }\end{array}$} \\
\hline Metronidazole & $\mathrm{AC}$ & 287.91 & 0.0233 & $>0.999$ & & 2.4478 & 0.893 & & & & & & & \\
\hline Dimetridazole & AC & 257.162 & 0.0565 & $>0.999$ & & 0.8098 & 0.885 & & & & & & & \\
\hline $\begin{array}{l}\text { Tinidazole } \\
\text { Ronidazole }\end{array}$ & $A C$ & 378.283 & 0.0246 & $>0.999$ & & 1.807 & 0.928 & & & & & & & \\
\hline Tyrosin & $\begin{array}{l}\text { SWCNT } \\
\text { MWCNT }\end{array}$ & & & & $\begin{array}{l}0.097 \pm 0.004 \\
0.127 \pm 0.004\end{array}$ & $\begin{array}{l}0.910 \pm 0.001 \\
0.650 \pm 0.001\end{array}$ & $\begin{array}{l}0.983 \\
0.989\end{array}$ & & & & & & & Ji et al. (2010) \\
\hline Fluoroquinolone & Bentonite & 147.1 & 0.0106 & 0.9392 & 2.61 & 0.04488 & 0.9006 & & & & 99 & 0.3571 & & Genç et al. (2013) \\
\hline $\begin{array}{l}\text { Ciprofloxacin } \\
\text { (CIP) }\end{array}$ & $\begin{array}{l}\text { Bentonite } \\
\text { AC }\end{array}$ & & & & & & & $\begin{array}{c}137.1 \\
93.49\end{array}$ & $\begin{array}{l}0.065 \\
0.049\end{array}$ & $\begin{array}{l}0.817 \\
0.952\end{array}$ & $\begin{array}{c}138.9 \\
95.24\end{array}$ & $\begin{array}{l}0.0052 \\
0.0033\end{array}$ & $\begin{array}{l}0.999 \\
0.998\end{array}$ & $\begin{array}{l}\text { Genç and Dogan } \\
\text { (2015) }\end{array}$ \\
\hline
\end{tabular}




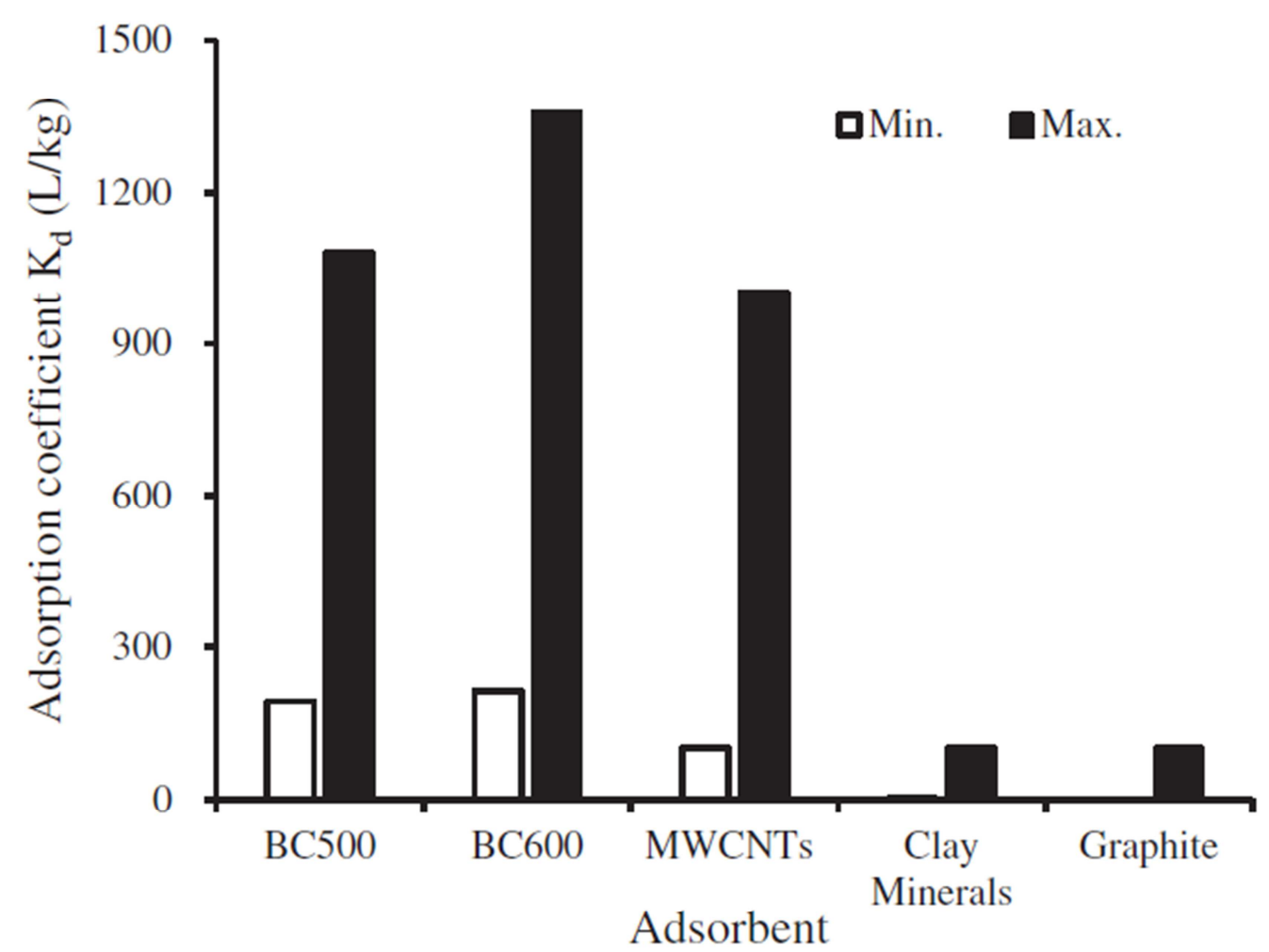

Fig. 1. Adsorption coefficient $\left(\mathrm{K}_{\mathrm{d}}\right)$ for the removal of sulfamethoxazole by different adsorbents.

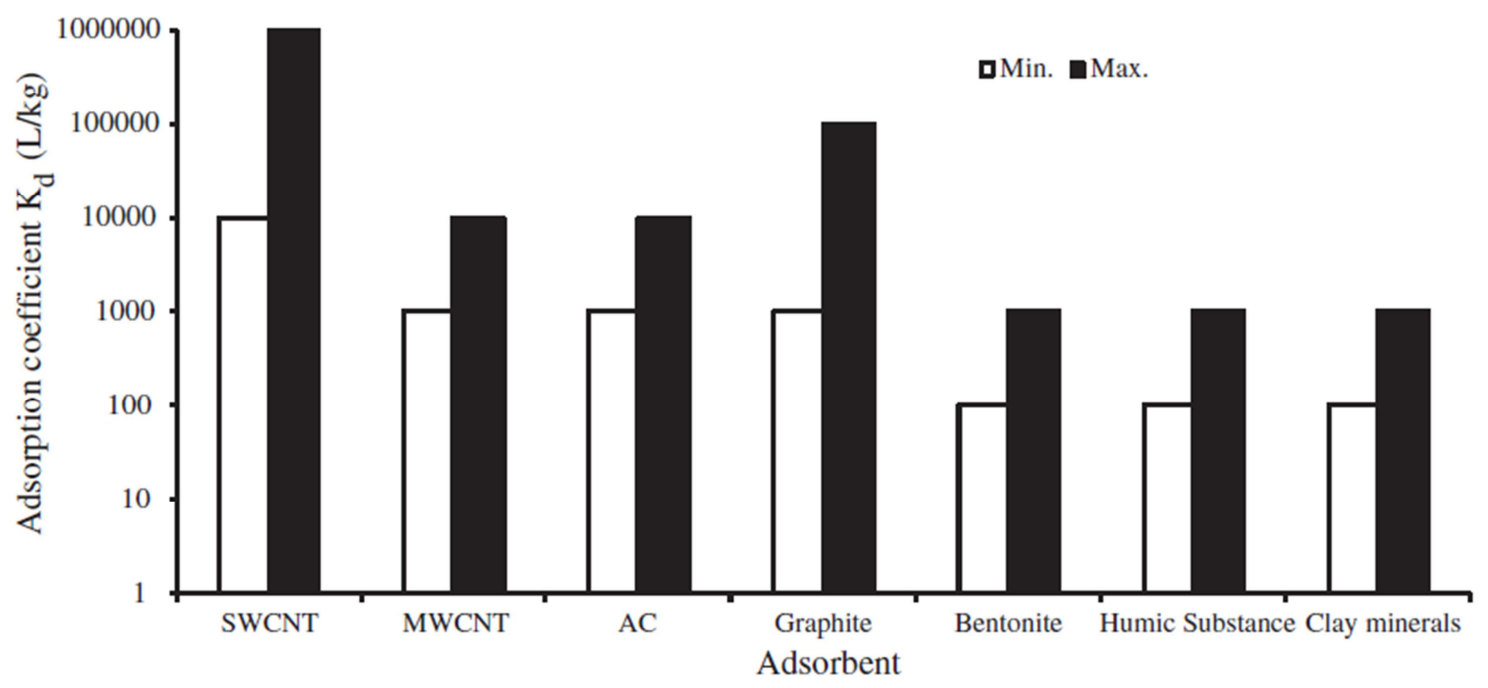

Fig. 2. Adsorption coefficient $\left(\mathrm{K}_{\mathrm{d}}\right)$ for the removal of tetracycline by different adsorbents. 


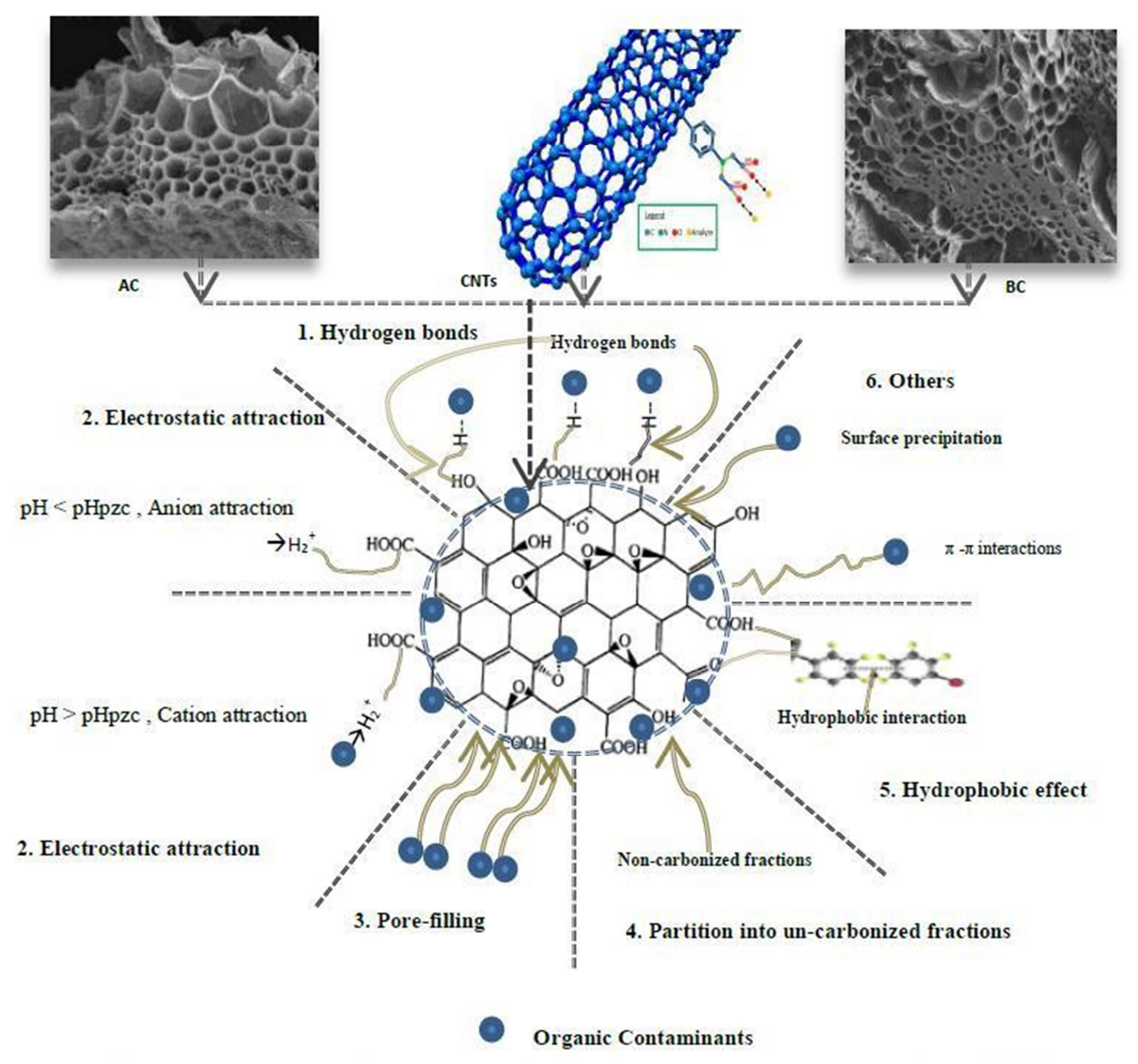

Fig. 3. Adsorption mechanism during the adsorption of antibiotics by carbonaceous materials. Modified from Tan et al. (2015). 


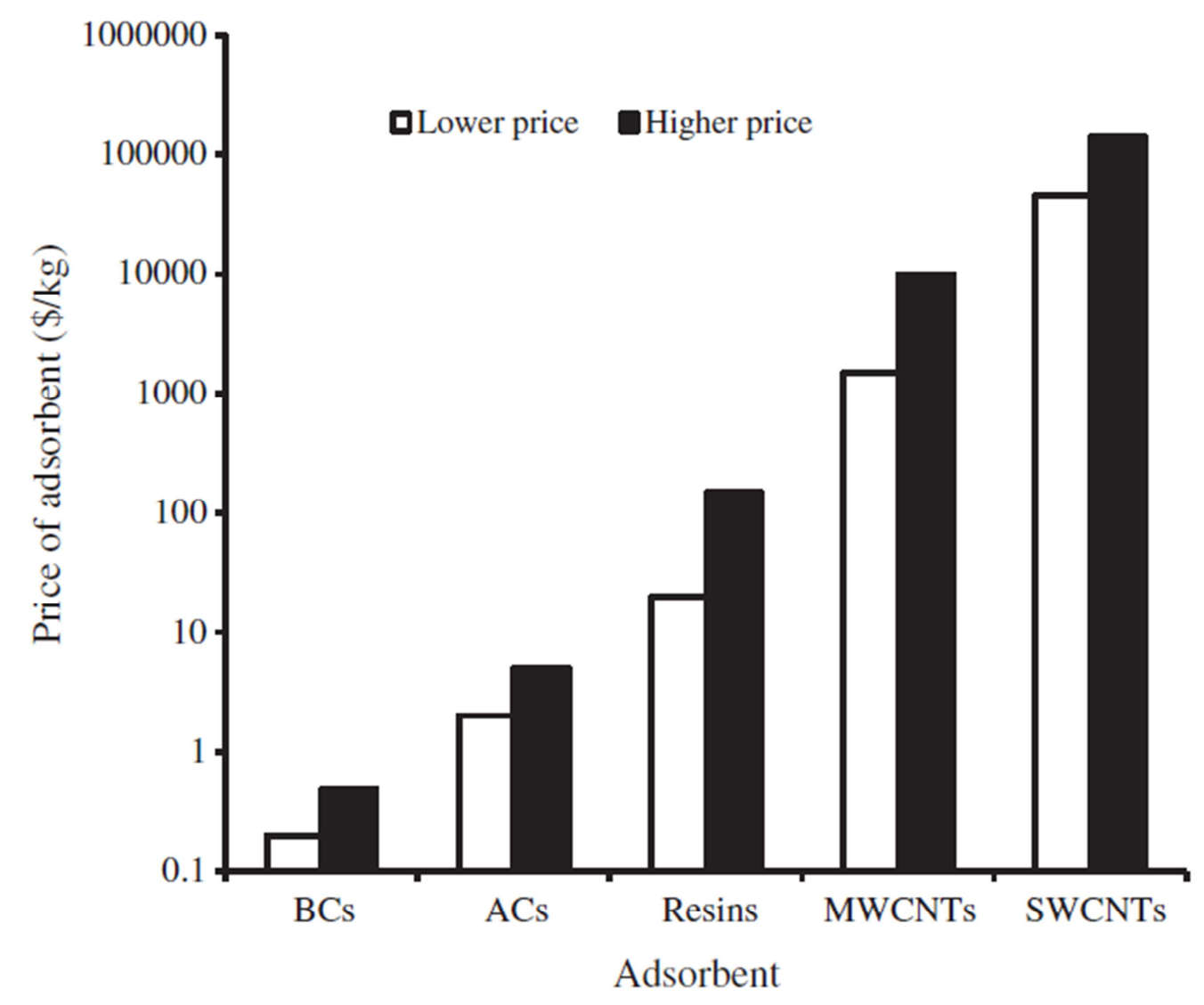

Fig. 4. The commercial price of different adsorbents. 